\title{
A Review Paper on the Role of Terrestrial Carbon Stocks for Climate Change Mitigation Mechanisms
}

\author{
Yitayal Tebeje \\ Department of Natural Resource Management, Debre Markos University P.O Box. 269, Ethiopia
}

\begin{abstract}
Global warming is among the greatest terrible horrors of the modern times. The global carbon cycle is taking place in three main reservoirs (the oceans, the atmosphere, and terrestrial systems), which store carbon in different forms and varying amounts. The forest ecosystems have large potential to act as a temporary and long-term carbon (C) pool. Global forest vegetation stores $283 \mathrm{Gt}$ of carbon in its biomass, $38 \mathrm{Gt}$ in dead wood and $317 \mathrm{Gt}$ in soils (top $30 \mathrm{~cm}$ ) and litter. Globally, the litter C pool accounts for an estimated 5\% (43 Pg) of all forest ecosystem C stocks. Agroforestry practices can reduce or remove significant amounts of GHGs through increased carbon storage in biomass above-ground and below-ground and in soil organic carbon. Roots are an important part of the $\mathrm{C}$ balance, because they transfer large amounts of $\mathrm{C}$ into the soil. Grasslands, including rangelands, shrublands, pastureland, and cropland sown with pasture and fodder crops, covered approximately 3.5 billion ha in 2000, representing 26 percent of the world land area and 70 percent of the world agricultural area, and containing about 20 percent of the world's soil carbon stocks. Soils are the largest carbon reservoirs of the terrestrial carbon cycle 1500-1550 Gt of organic soil carbon and soil inorganic $\mathrm{C}$ approximate $750 \mathrm{Gt}$ both to $1 \mathrm{~m}$ depth. On a global scale, carbon loss from soils is mainly associated with soil degradation, including accelerated erosion and mineralization, and land use change, and has amounted to 78+/- 12 Gt since 1850. The idea of Reducing Emissions from Deforestation and forest Degradation (REDD) was conceived by United Nations Framework Convention on Climate Change (UNFCCC) as the main carbon emission reduction mechanism by developing countries. The implementation of improved land management practices to build up carbon stocks in terrestrial ecosystems is a proven technology for reducing the concentration of carbon dioxide (CO2) in the atmosphere - offsetting emissions from other sources and drawing down atmospheric $\mathrm{CO} 2$.
\end{abstract}

Keywords: Carbon sequestration, Terrestrial carbon, Global warming and Carbon stocks.

DOI: $10.7176 / \mathrm{JEES} / 10-8-04$

Publication date:August $31^{\text {st }} 2020$

\section{INTRODUCTION}

Carbon is present in the nonliving environment as carbon dioxide $\left(\mathrm{CO}_{2}\right)$ gas in the atmosphere, as dissolved carbon in water (forming bicarbonate and carbonate solutions), and in carbonate rocks, coal, petroleum, natural gas, and dead organic matter (humus). It is found in the atmosphere primarily as $\mathrm{CO}_{2}, \mathrm{CH}_{4}$, and chlorofluorocarbons (Brown, S. and P. Leonard, 2004)

Greenhouse gas emission is becoming a critical issue, as there is a growing awareness all over the world about its adverse impact and the consequent on climate change. At the dawn of third millennium, greenhouse gases are widely accepted by international scientific community as one of the potential threats to the existence of human kind coupled with extinction of other flora and fauna. The greenhouse gases with special optical properties that are responsible for climate warming include carbon dioxide $\left(\mathrm{CO}_{2}\right)$, water vapors, Methane $\left(\mathrm{CH}_{4}\right)$, Nitrous oxide $\left(\mathrm{N}_{2} \mathrm{O}\right)$, Nitrogen oxides (NOx), stratospheric ozone (O3), carbon monoxide $(\mathrm{CO})$ and Chlorofluorocarbons (CFC's). Among all these greenhouse gases, $\mathrm{CO}_{2}$ plays a leading role as it contributes to $50 \%$ of the total greenhouse effect (Bhardwaj SD, Panwar P, 2003).

According to IPCC (2001) report, since 1800 the concentrations of $\mathrm{CO}_{2}$ in the Earth's atmosphere have increased from around 280 parts per million (ppm) (by volume) to a current value close to $370 \mathrm{ppm}$. The increase coincides with the industrialization of human society and there is good evidence to show that it is caused by emissions of $\mathrm{CO}_{2}$ arising from human activities. The most important contributor to the recent increase in the global stock of atmospheric $\mathrm{CO}_{2}$ is the burning of fossil fuels (e.g. in power stations) and from the deforestation of land, particularly in the tropics. Carbon dioxide, along with a number of other gases present at lower concentrations (so called 'trace gases' such as methane $\left(\mathrm{CH}_{4}\right)$ and nitrous oxide $\left(\mathrm{N}_{2} \mathrm{O}\right)$ ), traps thermal radiation emitted from the Earth's surface and so gives rise to warming of the Earth's atmosphere. This warming (known as the 'greenhouse effect'), enhanced by the accumulation of these gases particularly over the 19th and 20th centuries has led to a global mean increase in surface temperature of about $0.6^{\circ} \mathrm{C}$ (IPCC, 2001). However, the challenges of climate change can be effectively overcome by the storage of carbon in terrestrial carbon sinks viz. plants, plant products and soils for longer periods of time.

Richards JF and Flint EP, (1993) reported that, about $80 \%$ of the world's potential for increasing Carbon storage in forests (estimated at 60-87 Pg Carbon from now up to 2050) lies in developing countries (Brown S, 1995). The forest woodland system sequestered more Carbon than all other categories collectively, but the 
proportion of total Carbon in this class progressively declined throughout the century from $73 \%$ in 1880 to $63 \%$ in 1980 .

The possibility that forests and agricultural land might be manipulated to mitigate $\mathrm{CO}_{2}$ emissions was recognized in the United Nations Framework Convention on Climate Change (UNFCCC) in 1992. The Kyoto Protocol in 1997 endorsed the idea not only that governments should employ policies to enhance the land carbon sink capacities of their territories but also that such mitigation could be set against requirements for reductions in emissions from fossil fuel consumption.

\section{Objectives}

The specific objectives of this review paper are:

(1) To highlight the potential of different carbon pools in carbon sequestration to mitigate climate change problem,

(2) To review the values of terrestrial ecosystem management practices in carbon sinks as Climate change mitigation requires the management of terrestrial carbon $(\mathrm{C})$ either by creating new $\mathrm{C}$ sinks or by preserving existing ones.

(3) To review the role of carbon sequestration for ecosystem functions and services

\section{METHODOLOGY}

This Seminar paper is exclusively a review paper, so all of the information has been collected from the secondary sources. In preparing this paper I read through various relevant books, journals, proceedings, reports, publications etc. I have also searched related internet web sites to collect information. I got valuable comments, suggestions and information from my colleagues and course instructors. Having collected all the relevant information concerning the topic, I myself compiled and prepared this seminar paper.

\section{REVIEW OF FINDINGS}

\subsection{The global carbon cycle}

There are five global C pools, of which the largest oceanic pool is estimated at $38000 \mathrm{Pg}$ and is increasing at the rate of $2.3 \mathrm{Pg} \mathrm{C} \mathrm{yr-1.} \mathrm{The} \mathrm{geological} \mathrm{C} \mathrm{pool,} \mathrm{comprising} \mathrm{fossil} \mathrm{fuels,} \mathrm{is} \mathrm{estimated} \mathrm{at} 4130 \mathrm{Pg}$, of which $85 \%$ is coal, $5.5 \%$ is oil and $3.3 \%$ is gas. As stated in Schrag (2007), verified reserves of fossil fuel include $678 \mathrm{Pg}$ of coal (3.2 $\mathrm{Pg} \mathrm{yr}^{-1}$ of production), $146 \mathrm{Pg}$ of oil (3.6 Pg yr-1 of production) and $98 \mathrm{Pg}$ of natural gas (1.5 pg yr-1 of production). Currently, coal and oil each account for approximately $40 \%$ of global $\mathrm{CO}_{2}$ emissions. Thus, the fossil fuel pool is depleting as a result of fossil fuel combustion, at the rate of $8.3 \mathrm{Pg} \mathrm{C} \mathrm{yr}-1$.

The third largest pool is in the soil, pedologic and is estimated at $2500 \mathrm{Pg}$ to $1 \mathrm{~m}$ depth. This pool has two distinct components: i). Soil organic C (SOC) pool which is estimated at $1550 \mathrm{Pg}$ includes highly active humus and relatively inert charcoal C (Batjes, 1996). It comprises a mixture of: plant and animal residues at various stages of decomposition; substances synthesized microbiologically and/or chemically from the breakdown products; and the bodies of live micro-organisms and small animals and their decomposing products (Schnitzer, 1991).

ii). Soil inorganic C (SIC) pool estimated at $950 \mathrm{Pg}$, includes elemental C and carbonate minerals such as calcite, and dolomite, and comprises primary and secondary carbonates (Batjes, 1996). The primary carbonates are derived from the weathering of parent material. In contrast, the secondary carbonates are formed by dissolution of $\mathrm{CO}_{2}$ in soil air into dilute carbonic acid and its interaction with calcium $\left(\mathrm{Ca}^{+2}\right)$ and magnesium $\left(\mathrm{Mg}^{+2}\right)$ brought in from outside the local ecosystem (e.g. calcareous dust, irrigation water, fertilizers, manures). The SIC is an important constituent of soils in arid and semi-arid regions.

The fourth largest $\mathrm{C}$ pool is the atmospheric pool comprising $\sim 800 \mathrm{Pg}$ of $\mathrm{CO}_{2}-\mathrm{C}$, and is increasing at the rate of $4.2 \mathrm{Pg} \mathrm{C} \mathrm{yr-1} \mathrm{or} 0.54 \% \mathrm{yr}^{-1}$. The smallest among the global $\mathrm{C}$ pools is the biotic pool, which is estimated at 620 $\mathrm{Pg}$, comprising $560 \mathrm{Pg}$ of live biomass and $60 \mathrm{Pg}$ of detritus material. The pedologic and biotic $\mathrm{C}$ pools together are called the terrestrial $\mathrm{C}$ pool estimated at approximately $3120 \mathrm{Pg}$. The terrestrial and atmospheric $\mathrm{C}$ pools strongly interact with one another through photosynthesis and respiration.

The strong interactions between the atmospheric, pedologic and the biotic $\mathrm{C}$ pools comprise important components of the global carbon cycle (GCC). The atmospheric pool is connected to the oceanic pool, which absorbs 92.3 Pg yr-1 and releases $90 \mathrm{Pg}$ yr-1 with a net positive balance of 2.3 Pg C yr-1. 


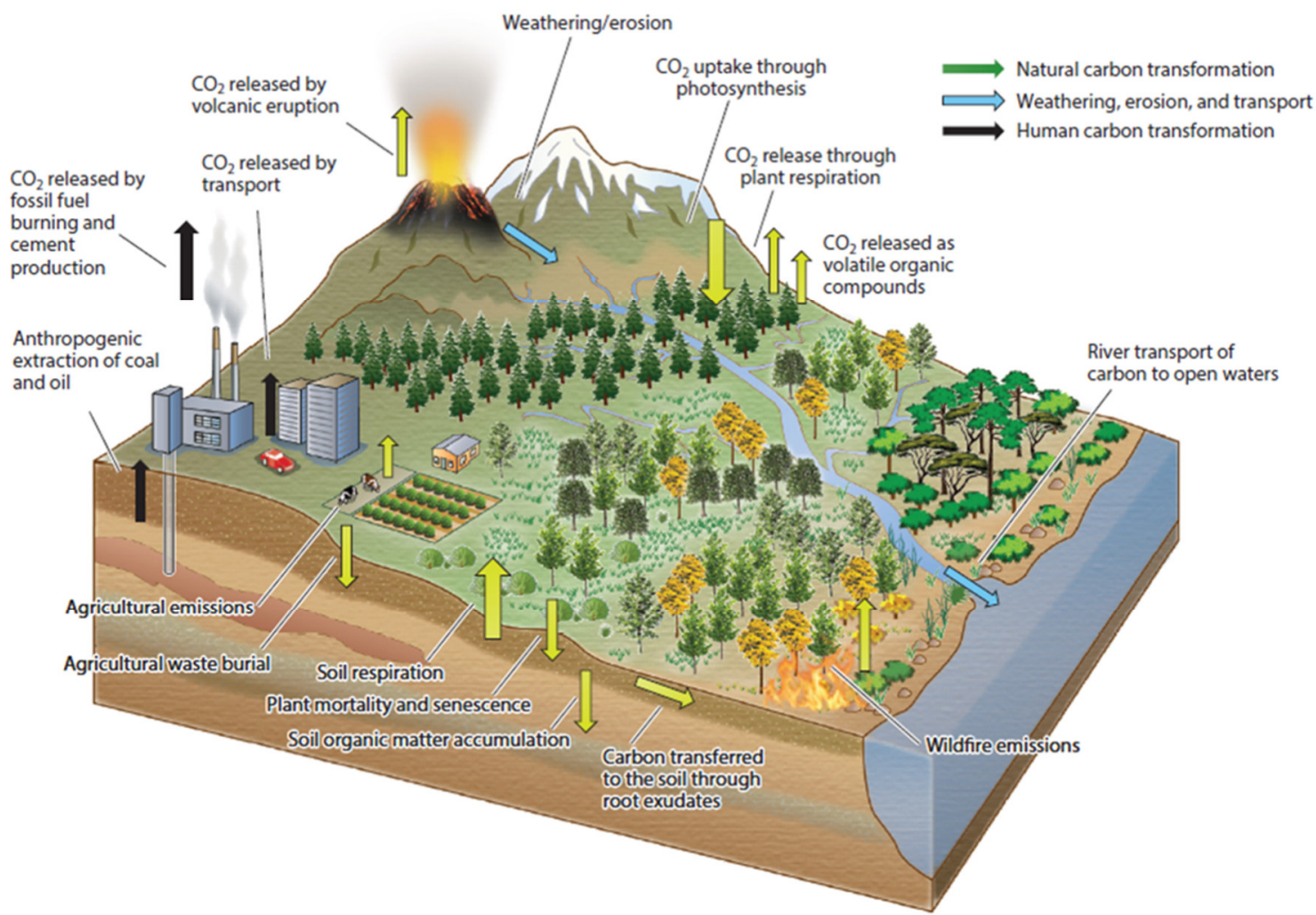

Figure 1: The primary flows and exchanges that constitute the terrestrial carbon cycle, including uptake through photosynthesis, release to the atmosphere through both anthropogenic (fossil fuel emissions, biomass burning, land use) and natural emissions (autotrophic and heterotrophic respiration, wildfires, volcanic eruptions), and weathering, erosion, and transport.(Source: Keenan T.F. and Williams C.A. (2018); Figure modified with permission from Diana Swantek, Lawrence Berkeley National Lab.)

\subsection{Overview of Global forest carbon stocks:}

The forest ecosystems have large potential to act as a temporary and long-term carbon (C) pool (Dixon et al. 1994). Approximately $80 \%$ aboveground and $40 \%$ underground terrestrial C is stored in forests (Cao and Woodward 1998).

Global forest vegetation stores $283 \mathrm{Gt}$ of carbon in its biomass, $38 \mathrm{Gt}$ in dead wood and $317 \mathrm{Gt}$ in soils (top $30 \mathrm{~cm}$ ) and litter. Therefore, the total carbon content of forest ecosystems has been estimated at $638 \mathrm{Gt}$ for 2005 , which is more than the amount of carbon in the entire atmosphere. This standing carbon is combined with a gross terrestrial uptake of carbon, which was estimated at $2.4 \mathrm{Gt}$ a year, a good deal of which is sequestration by forests. According to the Intergovernmental Panel on Climate Change report, the conservation and restoration of forests can considerably reduce emissions at a low cost and with potential co benefits for adaptation and sustainable development. About $80 \%$ of the world's potential for increasing Carbon storage in forests (estimated at $60-87 \mathrm{Pg}$ Carbon from now up to 2050) lies in developing countries (Brown, 1995).

Forests ecosystems sequester and store more carbon than any other terrestrial ecosystem and hence are an important natural 'brake' on climate change. When forests are destroyed or degraded, their stored carbon is released into the atmosphere as carbon dioxide $\left(\mathrm{CO}_{2}\right)$. Tropical deforestation is estimated to have released of the order of 1-2 billion tonnes of carbon per year during the $1990 \mathrm{~s}$, roughly $15-25 \%$ of annual global greenhouse gas emissions (Malhi and Grace 2000, Fearnside and Laurance 2003, 2004,). The largest source of greenhouse gas emissions in most tropical countries is from deforestation and forest degradation. In Africa, for example, deforestation accounts for nearly $70 \%$ of total emissions (FAO 2005).

Climate change or global warming due to the rise in greenhouse gases into the atmosphere, primarily carbon dioxide $\left(\mathrm{CO}_{2}\right)$, is one of the most urgent global problems. Among anthropogenic GHGs, $\mathrm{CO}_{2}$ is the most abundant and is responsible for more than half the radiation associated with the greenhouse effect (Solomon and Srinivasan, 1996). In 1992, at the Earth Summit in Rio de Janeiro, the United Nations Framework Convention on Climate Change (which included voluntary pledges to reduce greenhouse gas emissions) was opened for signature. Subsequent negotiations led to the 1997 Kyoto Protocol, under which the developed nations agreed to specified reductions in their emissions of greenhouse gases. 
IPCC, (2007) stated that an increase in the atmospheric concentration of carbon dioxide $\left(\mathrm{CO}_{2}\right)$ (from 280 parts per million (ppm) in the pre-industrial era to $390 \mathrm{ppm}$ in 2010, an enrichment of 39 percent) and other greenhouse gases (GHGs, such as nitrous oxide $\left(\mathrm{N}_{2} \mathrm{O}\right)$ and methane $\left(\mathrm{CH}_{4}\right)$, may enhance radiative forcing and alter the Earth's mean temperature and precipitation.

Three strategies are available for lowering $\mathrm{CO}_{2}$ emissions to mitigate climate change (Schrag, 2007): (i) reducing global energy use; (ii) developing low or no-C fuel; and (iii) sequestering $\mathrm{CO}_{2}$ from point sources or atmosphere using natural and engineering techniques.

The most voluminous greenhouse gas produced by humans is carbon dioxide $\left(\mathrm{CO}_{2}\right)$. In calculating overall carbon emissions, the Protocol allows certain removals of carbon by a nation's forests and soils — "carbon sinks" — to be counted and deducted from emissions. Thus, one option for mitigating greenhouse gas emissions - and thus possible climate change - is to increase the amount of carbon stored in forests. Mitigating climate change by enhancing forest carbon sequestration may be a relatively low-cost option and would likely yield other environmental benefits (CRS Report RL33826, 2007). Afforestation is regarded as an effective measure to prevent the global warming by sequestrating $\mathrm{C}$ both in biomass and in soil. Trees and understory vegetation assimilate carbon dioxide $\left(\mathrm{CO}_{2}\right)$ from the atmosphere and store $\mathrm{C}$ in plant biomass.

Trees act as a sink for $\mathrm{CO}_{2}$ by fixing carbon during photosynthesis and storing excess carbon as biomass. The net long-term $\mathrm{CO}_{2}$ source/sink dynamics of forests change through time as trees grow, die, and decay. In addition, human influences on forests (e.g. management) can further affect $\mathrm{CO}_{2}$ source/sink dynamics of forests through such factors as fossil fuel emissions and harvesting/utilization of biomass. However, increasing the number of trees might potentially slow the accumulation of atmospheric carbon (Moulton and Richards, 1990). Moreover, C sequestration in trees is also influenced by the variation of wood density. At identical volume, trees with higher wood density (most deciduous species) accumulate more $\mathrm{C}$ than those with light wood density (most coniferous species).

The magnitude and progress of the changes in $\mathrm{C}$ storage following afforestation are highly various because of the influence of different factors, such as climatic condition, soil property, tree species, and present management (Paul et al. 2002).

According to the FAO (2016), reforestation, afforestation, reduced deforestation and sustainable forest management would enable increased carbon sequestration. Examining natural carbon mitigation options that safeguard the production of food and fibre and habitat for biological diversity. Griscom et al., (2017) put forward the most feasible options that the maximum potential of these natural options is $23.8 \mathrm{PgCO} 2 \mathrm{e} 2 \mathrm{y}-1$ at a 2030 reference year. Appropriate forest management is vital for both carbon and forest productivity and to address potential risks from pests, disease, fire and extreme weather, as well as maintaining biodiversity. The soil in forests hold $39 \%$ of the carbon stored in soil and thus management practices need to address the soil carbon pool.

The natural forest system is declining due to urbanization, expanding farm land requirement and increasing the demand of timber production (Chakravarty et al., 2011). These alterations cascade through the ecosystem, resulting in increased temperature altered rainfall patterns and degraded soil profiles. Hence, apart from fossil fuel combustion, decimation of forest and its products could also be a factor that aids in changing global climate.

FIELD

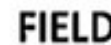

NPP

\section{$\left(1.0 \mathrm{tCha}^{-1} \mathrm{yr}^{-1}\right)^{\mathrm{b}}$}

REFORESTATION

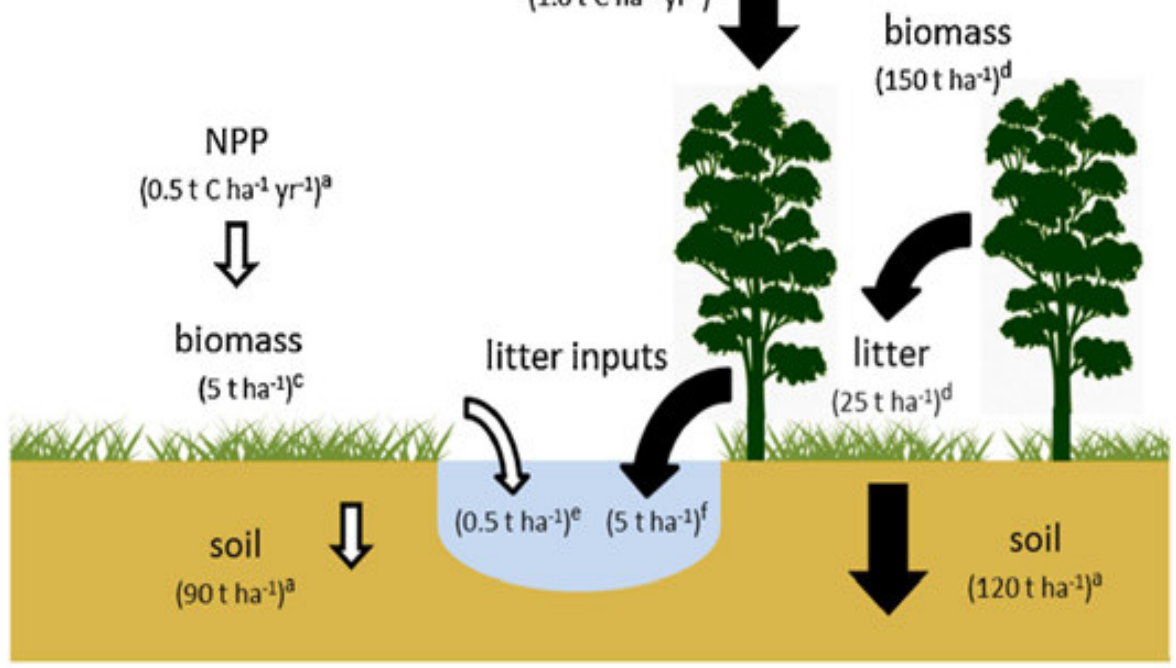

Figure 2: Carbon abatement in forest and fields: Source Cunningham et al., 2015 


\subsection{Estimation of Forest Carbon}

In order to recognize how forest ecosystems respond and feedback to climate change, we need to quantify carbon stocks in vegetation and soil in forest ecosystems. There are several methods currently used for estimation of forest biomass carbon (Yu et al., 2014): (1) Field measurement-based estimation using forest inventory data (Yu et al., 2014). Biomass data is a basic requirement for the estimation of carbon density and storage and can be acquired in different ways but fieldmeasured data is the most basic, direct and authentic (Pan YD, Birdsey RA, 2013). These methods include (a) the mean biomass density method [MBM] that directly measures biomass in sample plots and uses the average of total plot biomass for each forest type to get biomass for that type, requiring only inventory data on forest area. A biomass expansion factor (BEF) is used to convert stem volume to biomass to account for all components of trees; (b) the continuous biomass expansion factor method (CBM) expands on the MBM by treating BEF not as a constant but as a function of forest age, stand density, and type of site; and (c) continuous BEF method (CBM). Fang et al., (2007) derived an equation that accommodates changing BEF values over time from inventory data on forest area and volume. (2) Remote sensing-based techniques. Remote sensing data such as satellite imagery to aerial photo-imagery from low-flying airplanes may provide a useful means for measuring carbon stocks in forests (Brown 2002). 3) Micrometeorological techniques such as Eddy covariance technique and their upscaling (Nabuurs et al., 2010). (4) Large-scale ecosystem models as BIOME-BGC, LPJ, ORCHIDEE, or DLEM (Tian et al., 2012).

Each of these methods has its strengths and weaknesses (Nabuurs et al. 2010). For example, field measurement-based method provides estimates of both the carbon stock changes and the size of the stocks but has limited capability to forecast future changes.

Ecosystem models can explore the importance of ecosystem physiological responses to climate variability or increasing $\mathrm{CO}_{2}$, but most of them do not yet consider natural or human-induced disturbances (Karjalainen et al., 2003). So far, the estimates of the contemporary carbon balance still vary a lot (Nabuurs et al. 2010).

Table 1: Comparison of summary processes for forest carbon estimation. Source: Gurung (2008)

\begin{tabular}{|c|c|c|c|c|}
\hline Methods & IPCC (2006) & Pearson et al (2007) & Macolcken (1997) & $\begin{array}{l}\text { CCS (2007) and } \\
\text { CCB (2008) }\end{array}$ \\
\hline $\begin{array}{l}\text { Criteria for } \\
\text { stratification }\end{array}$ & $\begin{array}{l}\text { Climate zone, ecotype, soil } \\
\text { type, management regime } \\
\text { within land- use types }\end{array}$ & $\begin{array}{l}\text { Vegetation, soil, } \\
\text { topography }\end{array}$ & $\begin{array}{l}\text { Land-use, vegetation, } \\
\text { slope, drainage, } \\
\text { elevation, proximity to } \\
\text { settlement }\end{array}$ & $\begin{array}{l}\text { According to the } \\
\text { guidance } \\
\text { provided by IPCC }\end{array}$ \\
\hline $\begin{array}{l}\text { Carbon pools } \\
\text { to measure }\end{array}$ & $\begin{array}{l}\text { Above-ground biomass, } \\
\text { below-ground biomass, } \\
\text { dead wood, litter, and soil } \\
\text { organic matter), as well as } \\
\text { emissions of non- } \mathrm{CO}_{2} \\
\text { gases }\end{array}$ & $\begin{array}{l}\text { Above-ground } \\
\text { biomass, below- } \\
\text { ground biomass, } \\
\text { dead wood, litter, soil } \\
\text { organic carbon, and } \\
\text { wood products }\end{array}$ & $\begin{array}{l}\text { Above-ground } \\
\text { biomass/necromass, } \\
\text { below-ground biomass } \\
\text { (tree roots), soil } \\
\text { carbon and standing } \\
\text { litter crop }\end{array}$ & $\begin{array}{l}\text { Consider the } \\
\text { same pools } \\
\text { covered under } \\
\text { the IPCC } \\
\text { guidelines }\end{array}$ \\
\hline $\begin{array}{l}\text { Methods / } \\
\text { values for } \\
\text { estimation }\end{array}$ & $\begin{array}{l}\text { Allometric equations for } \\
\text { trees } \\
\text { Ratio of BGB to AGB for } \\
\text { tropical dry forest } \\
0.56 \text { for }<20 \text { tons AGB/ ha } \\
0.28 \text { for }>20 \text { tons AGB/ ha } \\
\text { Carbon fraction (CF): } 0.47 \\
\text { (default value for all parts) }\end{array}$ & $\begin{array}{l}\text { Allometric equations } \\
\text { for trees, destructive } \\
\text { harvesting for shrubs, } \\
\text { herbs and litter } \\
\text { Root : Shoot ratio } \\
\text { BGB }=\text { exp (-1.0587 + } \\
0.8836 \times \text { in AGB) } \\
\text { Carbon content }=0.5 \\
\text { ( } 50 \% \text { of total biomass) }\end{array}$ & $\begin{array}{l}\text { Equation for moist } \\
\text { climate, annual rainfall } \\
(1,500-4,000 \mathrm{~mm}) \\
y=38.4908-11.7883 \\
D+1.1926 \mathrm{D}^{2} \\
\text { Root }: \text { Shoot ratio }= \\
0.10 \text { or } 0.15 \\
\text { Carbon content }=0.5 \\
\text { (50\% of total biomass) }\end{array}$ & $\begin{array}{l}\text { According to the } \\
\text { guidance } \\
\text { provided by IPCC }\end{array}$ \\
\hline
\end{tabular}

\subsection{Carbon sequestration by tree plantations}

The idea of tree plantations as a sink for carbon dioxide has gained momentum over the last decade (Andrasko 1990, Cairns \& Meganck 1994). Though all the plant species having photosynthesis absorb a part of carbon from the atmosphere, trees are considered as the largest individual carbon sinks. Theoretically, the carbon absorbing capacity is high in the initial stages of plant growth because metabolism is comparatively high. One half of a tree's dry weight is carbon (Nowak, 1994).

Among the various methods available, allometric equations are the most common and reliable method for determining tree biomass (Gower ST et al., 1999) and carbon storage and flux (Gahagan A et al., 2015) and a large number of allometric biomass equations have been developed for different forest tree species in many parts of the world. Among the tree growth variables, diameter and height are most commonly used, due to their availability and easy to measure in forest inventories.

The use of tree plantations can be multifunctional: soil rehabilitation, direct economic rewards and carbon sequestration (Parrotta, 1992). Nevertheless, improved techniques, including the use of mixed-species plantations, should be tested to determine the most effective and productive use of the land for carbon sequestration, 
particularly in degraded lands (Brown et al., 1997). Results from previous research have indicated the capacity of the mixed-species stands to produce relatively high levels of biomass (Montagnini \& Porras 1998).

\subsection{Litter carbon stock}

Globally, the litter C pool accounts for an estimated 5\% (43 Pg) of all forest ecosystem C stocks (Pan et al., 2011). The Intergovernmental Panel on Climate Change recognizes litter carbon (C) as one of five C pools in forest ecosystems included in the Agriculture, Forestry and Other Land Use sector of annual national greenhouse gas inventories (IPCC, 2006).

Interspecific differences in the production and decomposition rate of litters explain the variations in litter $\mathrm{C}$ storage (Finzi et al., 1998). Deciduous tree species have a higher annual production of litters than the evergreen coniferous species. However, previous research showed that pine and spruce had more litter $\mathrm{C}$ than beech and oak (Jandl et al. 2007). It is mainly attributed to the slow decay rate of needle litters determined by the chemical composition, such as soluble carbohydrates and lignin concentrations (Paul et al., 2002).

\subsection{Root carbon stock}

Roots are an essential yet poorly understood component of terrestrial ecosystems. They play an important role in the carbon (C) cycle by contributing a significant fraction of ecosystem net primary production (Vogt et al., 1996). According to the study conducted on forest soils of eastern Amazonnia, fine roots make up more than $50 \%$ of the total $\mathrm{C}$ found in the upper $10 \mathrm{~cm}$ (Telles et al., 2003). Although the highest density of root biomass is found close to the soil surface, roots extend to depths $415 \mathrm{~m}$ in seasonally dry forests in eastern Amazo nia (Nepstad et al., 1994), where they are active in taking up water to sustain plant transpiration in the dry season (Jipp et al., 1998). Root lifetimes estimated in these studies ranged from 0.4 to 3.2 years.

Plant roots contribute to soil carbon not only through their death and decomposition, but also by rhizodeposition resulting from exudation, mucilage production and sloughing from living roots (Reeder JD, et al., 2001). In most temperate grassland ecosystems, $75-80 \%$ of the root biomass is in the top $30 \mathrm{~cm}$ of the soil but, because root growth, death and decomposition occur simultaneously and at different rates according to species and climatic conditions, accurate determination of carbon transfer from the various sources to the soil is difficult (Reeder JD, et al., 2001).

Recently, Gaudinski et al. (2001) used radiocarbon to estimate the mean age of fine root $\mathrm{C}$ in temperate ecosystems by comparing the radiocarbon (14C) content of fine root structural material with the measured record of change for $14 \mathrm{C}$ in atmospheric $\mathrm{CO}_{2}$. Radiocarbon values measured in live, dead, and mixed fine roots from temperate deciduous and coniferous forests corresponded to an average of 3-18 years elapsed since $\mathrm{C}$ was fixed from the atmosphere for three temperate forest sites, longer than estimates of root lifetime previously reported in the literature. High $14 \mathrm{C}$ values in roots could reflect one of several causes: (1) roots are long-lived and the 14C content reflects the mean age of the root; (2) roots are constructed from $\mathrm{C}$ that is already high in $14 \mathrm{C}$ because of recycling or storage within the plant; or (3) roots are constructed from $\mathrm{C}$ taken up from the soil.

The BGB, constituted by all the live roots, plays an important role in the carbon cycle by transferring and storing carbon in the soil. The dead litter biomass and woody debris are not a major carbon pool as these contribute to only small fraction of the carbon stocks of forests (Ravindranath N.H., Ostwald M., 2008). Root growth allows for the placement of plant tissue directly into the soil, creating a root $\mathrm{C}$ pool as deep as the rooting system occupies. Some studies suggest that root $\mathrm{C}$ pool size and soil organic $\mathrm{C}$ pool size have a direct relationship and that most soil organic matter is derived from roots (Kong and Six, 2010). This would mean that a change in root inputs, such as that engendered by switching from annual to perennial systems, would have a direct impact on soil organic matter even deep into the soil profile.

Temperature, moisture, O2, soil texture, and soil $\mathrm{C}$ levels all vary with soil depth and contribute to partial explanations for the size discrepancy between root and soil $\mathrm{C}$ pools.

\subsection{Agroforestry carbon sequestration}

Agroforestry systems are believed to have a higher potential to sequester $\mathrm{C}$ than pastures or field crops (Kirby and Potvin, 2007). This idea is based on the notion that tree incorporation in croplands and pastures would result in greater net aboveground as well as belowground $\mathrm{C}$ sequestration (Haile et al., 2008).

Agroforestry practices like alley cropping and silvopastures have the greatest potential for conserving and sequestering carbon because of the close interaction between crops, pasture, trees and soil (Nair PKR, 1998). Agroforestry practices can reduce or remove significant amounts of GHGs through increased carbon storage in biomass above-ground and below-ground and in soil organic carbon (IPCC, 2019). Agroforestry is recognized as an important component in climate-smart agriculture (defined as agriculture that brings humankind closer to safe operating spaces across spatial and temporal scales for food systems, in the context of climate change (Neufeldt et al. 2013).

The important elements of agroforestry systems that can play a significant role in the adaptation to climate 
change include changes in the microclimate, protection through provision of permanent cover, opportunities for diversification of the agricultural systems, improving efficiency of use of soil, water and climatic resources, contribution to soil fertility improvement, reducing carbon emissions and increasing sequestration, and promoting gender equity (Rao KPC, Verchot LV, Laarman J, 2007). The International Panel on Climate Change (IPCC) estimates that the current worldwide area under agroforestry is 400 million ha, which results in a carbon gain of 0.72 Mgha- 1 year- 1 . It is estimated that the potential carbon gain could increase to $26 \times 106$ Mgha- 1 year- 1 by 2010 and to $45 \times 106$ Mgha- 1 year-1 by 2040 (Watson RT, et al., 2000). The use of agroforestry crops is a promising tool for reducing atmospheric $\mathrm{CO} 2$ concentration through fossil fuel substitution.

A large number of estimates of $\mathrm{C}$ sequestration and $\mathrm{C}$ losses in different land-use systems are available. Today, agroforestry is recognized as an integrated applied science that has the potential for addressing many of the $30 \%$ of foliage dry weight constitute C (Schroth et al., 2002).

Global forestry and land use change combined, contributed annually about 4-6 PgCO2eq/y to the atmosphere in the years $1970-2009$ (Smith et al., 2014). This is about $12 \%$ of the total amount of greenhouse gasses emitted annually.

A summary of above-ground $\mathrm{C}$-sequestration rates in some major agroforestry systems around the world is presented in Tab. 2. The table indicates that the estimates of CSP in agroforestry systems are highly variable, ranging from 0.29 to $15.21 \mathrm{Mg}$ ha- $1 \mathrm{y}-1$.

Table 2: Mean vegetation (above- and belowground) carbon-sequestration potential of prominent agroforestry systems.

\begin{tabular}{lccl}
$\begin{array}{l}\text { Systems. } \\
\text { Agroforestry/land-use system }\end{array}$ & $\begin{array}{l}\text { Age }^{\mathrm{b}} \\
(\mathrm{y})\end{array}$ & $\begin{array}{l}\text { Mean vegetation C } \\
\left(\mathrm{Mg} \mathrm{ha}^{-1} \mathrm{y}^{-1}\right)\end{array}$ & Source \\
\hline Fodder bank, Ségou, Mali, W African Sahel & 7.5 & 0.29 & \multicolumn{1}{c}{ Takimoto et al. (2008b) } \\
Live fence, Ségou, Mali, W African Sahel & 8 & 0.59 & Takimoto et al. (2008b) \\
Tree-based intercropping, Canada & 13 & 0.83 & Peichlet al. (2006) \\
Parklands, Ségou, Mali, W African Sahel & 35 & 1.09 & Takimoto et al. (2008b) \\
Agrisilviculture, Chattisgarh, Central India & 5 & 1.26 & Swamyand Puri (2005) \\
Silvopasture, W Oregon, USA & 11 & 1.11 & Sharrowand Ismail (2004) \\
Silvopastoralism, Kurukshetra, India & 6 & 1.37 & Kaur et al. (2002) \\
Silvopastoralism, Kerala, India & 5 & 6.55 & Kumar et al. (1998a) \\
Cacao agroforests, Mekoe, Cameroon & 26 & 5.85 & Duguma et al. (2001) \\
Cacao agroforests, Turrialba, Costa Rica & 10 & 11.08 & Beer et al. (1990) \\
Shaded coffee, SW Togo & 13 & 6.31 & Dossa et al. (2008) \\
Agroforestry woodlots, Puerto Rico & 4 & 12.04 & Parrotta(1999) \\
Agroforestry woodlots, Kerala, India & 8.8 & 6.53 & Kumaret al. (1998a) \\
Home and outfield gardens & 23.2 & 4.29 & Kirby and Potvin (2007) \\
Indonesian homegardens, Sumatra & 13.4 & 8.00 & Roshetko et al. (2002) \\
Mixed species stands, Puerto Rico & 4 & 15.21 & Parrotta (1999)
\end{tabular}

Establishing agroforestry on land that currently has low tree cover has been identified as one of the most promising strategies to raise carbon stocks on currently productive land without compromising food and fiber production (Albrecht and Kandji 2003; Montagnini and Nair 2004). Agroforestry is the deliberate integration of trees or other woody perennials into field crop or livestock systems, in order to exploit synergies and complementarities between different structural elements of the system. Agroforestry has been shown in many instances to lead to more diverse, more productive and more sustainable agricultural production than less integrated approaches (Nair 2007).

Carbon stock increases resulting from conversion of treeless land to agroforestry have been estimated at 3 $\mathrm{Mg} \mathrm{C} \mathrm{ha-1} \mathrm{a-1} \mathrm{in} \mathrm{tropical} \mathrm{regions} \mathrm{(IPCC} \mathrm{2000).} \mathrm{Conversion} \mathrm{of} \mathrm{agricultural} \mathrm{land} \mathrm{to} \mathrm{agroforestry} \mathrm{has} \mathrm{also} \mathrm{been}$ reported to entail substantial co-benefits for farmers, such as enhanced soil fertility, resilience to weather extremes and additional sources of farm income (Ajayi et al., 2007).

Tree-based agricultural systems in many parts of the world have been shown to have higher carbon stocks than treeless farming systems (Luedeling et al., 2011; Nair et al. 2009a, b) and to provide more environmental services (Jose 2009; Paustian et al. 1998).

Global carbon markets have opened up the possibility of payments to farmers for their contribution to climate change mitigation (Jose 2009). 
Agroforestry systems in humid tropical regions can store substantial amounts of carbon, but little attention has been paid to potential carbon stocks in drier areas. Only Smith et al. (2008) provide an estimate for agroforestry in warm dry areas (at $-0.73-1.39 \mathrm{Mg} \mathrm{C}$ ha-1 a -1 , with a mean of $0.33 \mathrm{Mg} \mathrm{C}$ ha-1 a -1 ), but these numbers were produced by assuming that agroforestry sequestered the same amount of carbon as agriculture with tillage and residue management.

A study of carbon storage and nitrogen cycling in silvopastoral systems on sodic soils was carried out by Kaur et al., (2002). They observed that compared to 'grass-only' systems, soil organic matter, biological productivity and carbon storage were greater in the silvopastoral systems.

The awareness of agroforestry's potential for climate change adaptation and mitigation systems is growing worldwide (Nair et al., 2009; Schoeneberger et al., 2012) offering the greatest $\mathrm{CO}_{2}$ sequestration potential among different land use system by 2040 (Noble et al., 2000). Agroforestry enhances carbon uptake by lengthening the growing season, expanding the niches from which water and soil nutrients are drawn and, in the case of nitrogen (N)-fixing species, enhancing soil fertility (Nair, 2009). The result is that when agroforestry systems are introduced in suitable locations, carbon is sequestered in the tree biomass and tends to be sequestered in the soil as well (Jose, 2009).

Agroforestry system combines trees and shrubs (perennial) with agronomic crops (annual or perennial). Therefore, they have both forest and grassland sequestration and storage patterns active (Schroeder et al., 1993). Globally, an estimated 700, 100, 300, 450, and 50-ton ha-1 of land are used for tree intercropping, multistrata systems, protective systems, silvopasture, and tree woodlots respectively (Nair et al., 2012). These practices have greater potential to increase carbon sequestration (Nair et al., 2009; Schoeneberger et al., 2009)

Thus, management of agricultural systems to sequester carbon has been accepted as a partial solution to climate change (Morgan et al., 2010). Sustainably managing agroforestry system, carbon can be retained in these systems for centuries (Dixon, 1995). Additionally, agroforestry systems have been recommended to reduce soil erosion and improve water quality (WBCSD, 2010). It is also purposeful for a variety of benefits and services such as increasing crop yields, reducing food insecurity, enhancing environmental services, and resilience of agroecosystems (Ajayi et al., 2011).

\subsection{Soil carbon stock}

The term "soil C sequestration" implies removal of atmospheric $\mathrm{CO}_{2}$ by plants through photosynthesis, and storage as long-lived, storage of fixed $\mathrm{C}$ as soil organic matter that is not rapidly decomposed. Soils are the largest carbon reservoirs of the terrestrial carbon cycle 1500-1550 Gt of organic soil carbon and soil inorganic C approximate $750 \mathrm{Gt}$ both to $1 \mathrm{~m}$ depth. About $60 \%$ organic carbons in the form of soil organic matter (SOM), and the remaining inorganic carbon in the form of inorganic compounds (e.g., limestone, or $\mathrm{CaCO} 3$ ). It is estimated that SOM stores about twice as much carbon as the atmosphere, and about three times more than forests and other vegetation. The strategy of soil $\mathrm{C}$ sequestration is cost-effective and environmentally friendly (Lal, 2004a). Changes in soil organic carbon levels can have significant effects on atmospheric $\mathrm{CO}_{2}$ levels. Each $1 \%$ increase in average soil organic carbon content could reduce atmospheric CO2 by up to $2 \%$ (State of Washington, 2012). Soil carbon sequestration is thus very cost effective and could take effect very quickly (FAO, 2008).

The global soil carbon pool amounts to $2500 \mathrm{Gt}$ (gigatons), whereas the biotic pool is $560 \mathrm{Gt}$ (Lal, 2004). Most agricultural soils have lost $30 \%$ to $75 \%$ of their antecedent soil organic carbon (SOC) pool or 30 to 40 t C ha-1. On a global scale, carbon loss from soils is mainly associated with soil degradation, including accelerated erosion and mineralization, and land use change, and has amounted to 78+/- $12 \mathrm{Gt}$ since 1850 . Consequently, the present organic carbon pool in agricultural soils is much lower than their potential capacity (Lal et al., 2007). The global potential of soil organic carbon sequestration is estimated at 0.6 to $1.2 \mathrm{Gt} \mathrm{C}$ year, comprising 0.4 to $0.8 \mathrm{Gt}$ $\mathrm{C}$ year through adoption of recommended management practices on cropland soils, 0.01 to $0.03 \mathrm{Gt} \mathrm{C}$ year on irrigated soils, and 0.01 to $0.3 \mathrm{Gt} \mathrm{C}$ year through improvements of rangelands and grasslands (Lal et al., 2007).

More than $40 \%$ of the total organic $\mathrm{C}$ in terrestrial ecosystems is stored in forest soill. Converting natural forests to agricultural land results in the mineralization of soil organic $\mathrm{C}$ (SOC), thus reducing SOC stocks and increasing atmospheric $\mathrm{CO}_{2}$ concentrations (Don, A. et al., 2011 and Harris, N. L.et al., 2012).

The decreases in SOC following a land-use change are difficult to predict due to variations in the factors that drive SOC mineralization, e.g., forest type, climate, and soil properties (IPCC, 2007). Understanding the effects of these factors is important for assessing the $\mathrm{C}$ flux between the soil and the atmosphere and for understanding the feedbacks within the global C cycle (Mahecha, M. D. et al., 2010)

SOM originally comes from atmospheric $\mathrm{CO}_{2}$ that is captured by plants through the process of photosynthesis. 


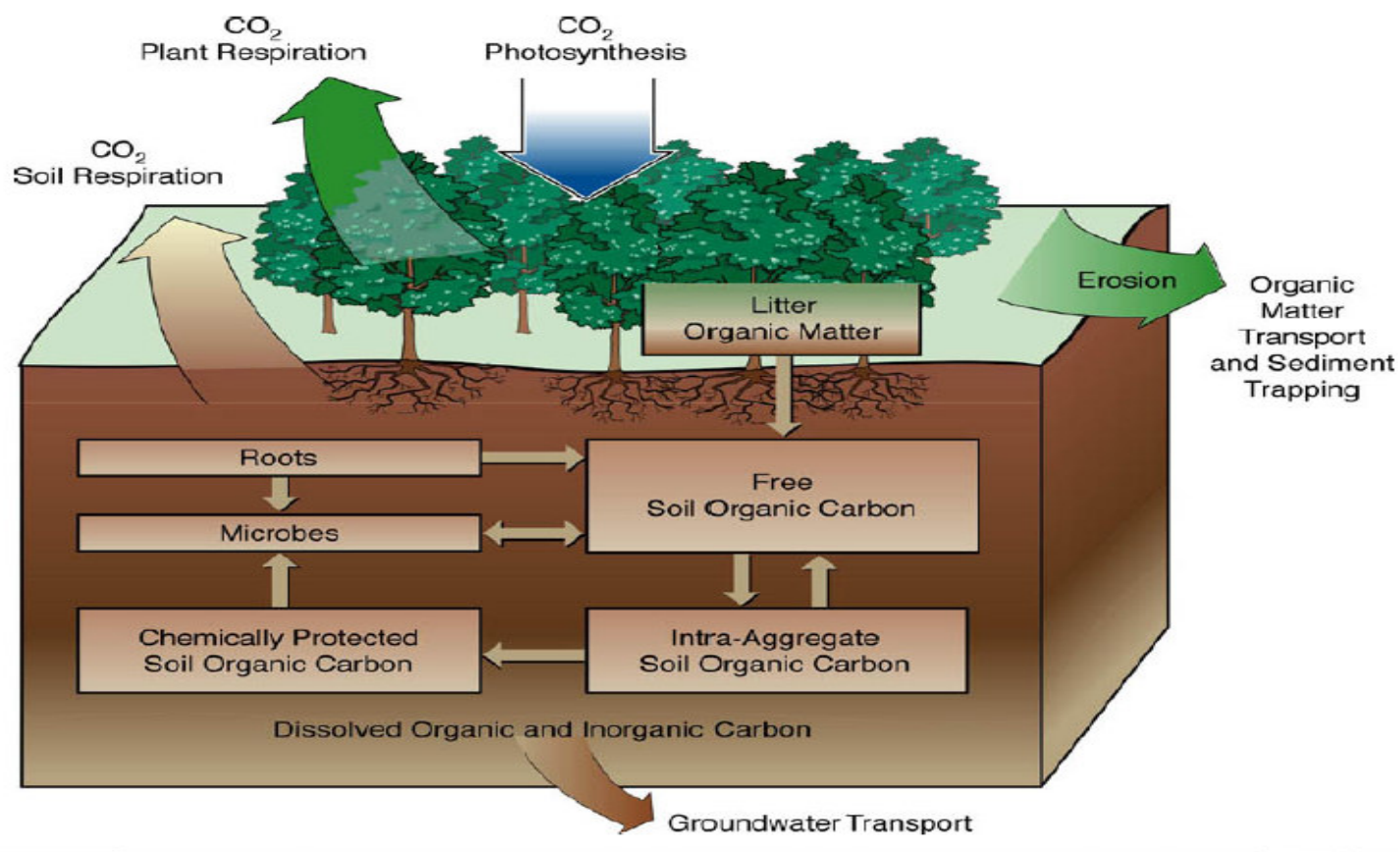

Figure 3: Carbon cycle with a focus on soils. (From Department of Energy "Carbon Sequestration Research and Development" 1999.) http://www.osti.gov/scitech/biblio/810722

SOM is a complex of carbon (C) compounds, and includes everything in or on the soil that is of biological origin. It includes plant and animal remains in various states of decomposition, cells and tissues of soil organisms, and substances from plant roots and soil microbes.

Organic carbon in the form of humus, the dark, spongy organic matter in soils, is highly resistant to soil microbial decomposition. It can be stored in the soil for hundreds to thousands of years, while other SOM (e.g., partially decomposed plant residues) can be quickly released as $\mathrm{CO} 2$ back into the atmosphere (State of Washington, 2012).

Based on its physical and chemical stability, SOC can be categorized into fast pool (decomposes within 1-2 years), intermediate pool (partially stabilized organic carbon with turnover times in the range 10-100 years), and slow pool (highly stabilized soil carbon which takes 100 to 1000 or more years to decompose) (Lefèvre et al., 2017). Over time, soil can thus serve as a carbon sink or source depending on soil properties, local climate and land use (IPCC, 2019).

At a global scale the relative distribution of the forms depends strongly on climate (Table 3). In general, SOC content increases with precipitation, with optimum levels in humid and cold climates (Eswaran et al., 1999). SIC is more important in soils of arid and semiarid zones (Eswaran et al., 1999; Table 3). Whereas SOC storage is related to biophysical factors and management practices, SIC is relatively resistant to these factors. Most soil C is found in organic form (Table 3; Eswaran et al., 1999), principally stored in the soil organic matter (SOM). SOC storage varies within regions and biomes

Table 3: SOC and SIC storage in the world. Source: summarized from Eswaran et al., 1999.

\begin{tabular}{lccccccc}
\hline Order & Area\% & \multicolumn{2}{c}{ Organic Carbon } & \multicolumn{2}{c}{ Inorganic Carbon } & \multicolumn{2}{c}{ Total Carbon } \\
\hline Gelisols & 8.6 & 316 & 20.4 & 7 & 0.8 & 323 & 12.9 \\
Histosols & 1.2 & 179 & 11.6 & 0 & 0.1 & 180 & 7.2 \\
Spodosols & 2.6 & 64 & 4.1 & 0 & 0.0 & 64 & 2.6 \\
Andisols & 0.7 & 20 & 1.3 & 0 & 0.0 & 20 & 0.8 \\
Oxisols & 7.5 & 126 & 8.1 & 0 & 0.0 & 126 & 5.1 \\
Vertisols & 2.4 & 42 & 2.7 & 21 & 2.3 & 64 & 2.6 \\
Aridisols & 12.0 & 59 & 3.8 & 456 & 48.0 & 515 & 20.6 \\
Ultisols & 8.4 & 137 & 8.8 & 0 & 0.0 & 137 & 5.5 \\
Mollisols & 6.9 & 121 & 7.8 & 116 & 12.2 & 237 & 9.5 \\
Alfisols & 9.6 & 158 & 10.2 & 43 & 4.5 & 201 & 8.0 \\
Inceptisols & 9.8 & 190 & 12.2 & 34 & 3.6 & 224 & 9.0 \\
Entisols & 16.2 & 90 & 5.8 & 263 & 27.7 & 353 & 14.2 \\
Miscellaneous & 14.1 & 24 & 1.5 & 0 & 0.0 & 24 & 1.0 \\
Total & 100.0 & 1526 & 100.0 & 940 & 100.0 & 2468 & 100.0 \\
\hline
\end{tabular}

The West African region is heavily dependent on climate sensitive sectors like agriculture, pastoral practices, 
forestry, fisheries, etc. These sectors are also C-based systems, emphasizing the pivotal role of both above and belowground $\mathrm{C}$ in the provisioning of ecosystem goods and services. SOC in various pools (either in plant biomass, litter or soil) constitutes a major driver of development in West Africa, and underlies major ecosystem services such as nutrient and soil moisture retention that contribute to plant productivity (Fischeret al., 2006).

Soil C, productivity, and degradative processes are closely related ( $\mathrm{V}^{\circ}$ agen et al., 2005; Roose and Bath 'es, 2001). C sequestration in soil provides benefits of improved soil quality (fertility, water holding capacity, resistance to erosion) and ecosystem functioning through contributions to ecosystem services: biomass production; storing, filtering and transforming nutrients and water; reducing soil temperature extremes and soil water loss; improving soil structure, water infiltration and water-holding capacity; hosting the biodiversity pool; acting as a platform for most human activities; providing raw materials; acting as $\mathrm{C}$ pool; and storing geological and archaeological heritage (Craswell and Leffroy, 2001; Table 4). As an important indicator of soil quality, SOC sequestration and conservation becomes a strategy to achieve food security. Organic $\mathrm{C}$ stocks alone have been shown to describe $78 \%$ of the variability of maize yields in Nigeria (Smaling and Dixon, 2006).

Table 4: Ecosystem services derived from soil organic carbon pool. Modified from Lal, 2004

\begin{tabular}{ll}
\hline On-site benefits & Off-site benefits \\
\hline Improvement in soil quality & Improvement of water quality \\
Increase in available water capacity & Decrease in transport of pollutants \\
Increase in nutrient retention & Biodegradation and denaturing of pollutants and contami- \\
Improvement in soil structure and tilth & nants \\
Buffering against changes in pH & Reduction in sediment load and siltation of water bodies \\
Enhancement of soil biotic activity & Decreased in non-point source pollution \\
Improvements in soil moisture and temperature regimes & Reduction in hypoxia risk in water bodies \\
Increase in agronomicfforest productivity & Less damage to coastal ecosystems \\
Increase in crop yield & Low risk by floods and sedimentation \\
Increase in use efficiency of input (fertilizers and water) & Decrease in transport of pollutants out of the ecosystem \\
Decrease in losses of soil amendments by runoff, erosion & Improvement in air quality \\
and leaching & Reduction in rate of enrichment of GHG \\
Improvements in soil conditions & Decrease in wind-borne sediments \\
Sustamability and food security & Improvement in biodiversity \\
Increase in sustainable use of perturbed soil and water re- & Increase in soil biodiversity \\
sources & Improvement in wildlife habitat and species diversity on re- \\
Food security increase & stored ecosystems \\
Additional income from trading C credits & Improvement in aesthetic and cultural value \\
Improvement in nutritional value of food and avoidance of & Desertification control \\
hidden hunger & Restoration of desertified lands \\
& Reversal of degradation trends \\
& Strengthening elemental recycling mechanisms \\
\hline
\end{tabular}

The newly increased soil $\mathrm{C}$ input under elevated $\mathrm{CO}_{2}$ may stimulate microbial degradation of soil organic matter decomposition, a phenomenon known as a "priming effect" (Bader and Cheng 2007). It has been shown that $\mathrm{CO}_{2}$-induced priming effect can override environmental effects (such as soil temperature, soil moisture, or soil properties) to accelerate soil organic matter decomposition rates, and hence resulting in expanded soil respiration to offset the extra soil $\mathrm{C}$ input due to increased plant growth, and a decrease in soil $\mathrm{C}$ content (Bader and Cheng 2007). Several studies have detected priming effects in temperate forests (Bader and Cheng 2007). Drake et al., (2011) also reported that total quantity of $\mathrm{C}$ entering the soil via litter fall and all belowground $\mathrm{C}$ inputs increased $17 \%$ from c. $1.50 \mathrm{~kg} \mathrm{C} \mathrm{m} 2$ year1 under ambient $\mathrm{CO}_{2}$ to c. $1.75 \mathrm{~kg} \mathrm{C} \mathrm{m} 2$ year1 under elevated $\mathrm{CO} 2$. However, these increases in $\mathrm{C}$ entering the soil under elevated $\mathrm{CO}_{2}$ was matched by increased $\mathrm{C}$ loss attributable to significant increases in fine and coarse root respiratory fluxes (i.e., autotrophic respiration) and a significant increase in heterotrophic respiration (Drake et al., 2011).

The effects of changes in soil management, such as increased soil disturbance and aeration, the addition of fertilizers, and changes in residue amount and quality, have often been cited as primary factors in the changes of soil organic matter from native levels (Gregory et al., 2016).

Many factors interact to determine how much $\mathrm{C}$ is transferred between pools and how much $\mathrm{C}$ remains in a particular pool. Soil temperature, moisture, O2 availability (Fontaine et al., 2007) are important environmental variables controlling the rate of decomposition and soil texture, and existing soil $\mathrm{C}$ levels determine the length of time $\mathrm{C}$ remains in the soil (Rasse et al., 2005).

Restoration of degraded soils has the potential to provide terrestrial sinks of $\mathrm{C}$ and reduce the rate of enrichment of atmospheric CO2. Woomer et al. (2004a) report a study in Senegal where the terrestrial C stocks ranged from $9 \mathrm{MgCha}-1$ in degraded savannahs in the north to $113 \mathrm{MgC}$ ha-1 in the remnant forests of the River Senegal valley. The results of Woomer et al. (2004a) further showed that the estimated total C stocks were 1019 $\mathrm{Tg}$ in 1965 and $727 \mathrm{Tg}$ in 2000, indicating a loss of 292MTC over 35 years. 
Table 5: Global carbon stocks in vegetation and soil carbon pools to the depth of $1 \mathrm{~m}$ (IPCC, 2000).

\begin{tabular}{lcccc}
\hline \multirow{2}{*}{ Biome } & \multirow{2}{*}{ Area $\left(\mathbf{1 0}^{\mathbf{9}} \mathbf{~ h a )}\right.$} & \multicolumn{3}{c}{ Global carbon stocks (Gt C) } \\
\cline { 3 - 5 } & & Vegetation & Soil & Total \\
\hline Tropical forests & 1.76 & 212 & 216 & 428 \\
Temperate forests & 1.04 & 59 & 100 & 159 \\
Boreal forests & 1.37 & 88 & 471 & 559 \\
Tropical savannas & 2.25 & 66 & 264 & 330 \\
Temperate grasslands & 1.25 & 9 & 295 & 304 \\
Deserts and semi-deserts & 4.55 & 8 & 191 & 199 \\
Tundra & 0.95 & 6 & 121 & 127 \\
Wetlands & 0.35 & 15 & 225 & 240 \\
Crop lands & 1.60 & 3 & 128 & 131 \\
\hline
\end{tabular}

\subsection{SOC and climate change}

The relation between soil organic carbon and climate change seems interesting to study as they can influence each other. The impact of climate change (mainly temperature rise) on SOC pool is negative whereas soil can be either a source or sink of carbon based GHGs depending on the circumstances (Lefèvre et al., 2017). Climate change affects the soil organic carbon dynamics as climatic variables regulate the different terrestrial carbon components and the processes that occur in this system.

Change in the global climate mainly temperature rise would affect soil organic carbon dynamics by altering its decomposition rate and plant litter production. Temperature increase would facilitate soil respiration, which lead to release of more GHGs into the atmosphere (Schlesinger, 1992). In addition, climate change affects the pattern of plant litter production (Cao \& Woodward, 1998) which is the prime source of new SOC.

Changes in amount of litter would likely lead a significant impact on the soil organic carbon stock dynamics and bio-geological cycles (Sayer et al., 2007). However, it is difficult to predict the impact of climate change on SOC due to the reason that litter production under climate change may decrease, increase or remain the same depending on the carbon dioxide concentration in the atmosphere (Cao \& Woodward, 1998; Yurova et al., 2010; Cao et al., 2011).

On the other side, SOC affects global climate by either being a source or sink of carbon based GHGs responsible for global warming. SOC serves as a sink to GHGs when atmospheric carbon dioxide is sequestrated by vegetation and the litter input from these plants ends up in the soil.

\subsection{Carbon sequestration in grasslands}

Grasslands and savannas cover $20 \%$ of the earth's land surface (Lieth H, 1975) and store 30\% of global soil organic carbon (Field C et al., 1998). Grasslands, including rangelands, shrublands, pastureland, and cropland sown with pasture and fodder crops, covered approximately 3.5 billion ha in 2000, representing 26 percent of the world land area and 70 percent of the world agricultural area, and containing about 20 percent of the world's soil carbon stocks (FAOSTAT, 2009). A large part of the world's grasslands is under pressure to produce more livestock by grazing more intensively, particularly in Africa's rangelands, which are vulnerable to climate change and are expected nonetheless to supply most of the beef and milk requirements in Africa (Reid et al., 2004).

Grassland ecosystems managed for livestock production represent the largest land-use footprint globally, covering more than one-quarter of the world's land surface (Asner GP, et al., 2004). Global estimates of the relative amounts of carbon in different vegetation types suggest that grasslands probably contribute $>10 \%$ of the total biosphere store (Eswaran H, 1993; Nosberger J, 2000). The annual Net Ecosystem Production (NEP) of temperate grassland is between 1 and $6 \mathrm{tC}$ ha- $1 \mathrm{yr}-1$ according to the radiation, temperature and water regimes, as well as to the nutrient status and the age of the sward (IPCC, 1996). Global estimates of the relative amounts of carbon in different vegetation types suggest that grasslands probably contribute $>10 \%$ of the total biosphere store (Nosberger J, 2000).

Primary production in overgrazed grasslands can decrease if herbivory reduces plant growth or regeneration capacity, vegetation density and community biomass, or if community composition changes (Chapman and Lemaire, 1993). If carbon inputs to the soil in these systems decrease because of decreased net primary production or direct carbon removal by livestock, soil carbon stocks will decline.

In broad terms, grasslands are ecosystems in which the dominant vegetation component is comprised of herbaceous species. There have been many approaches to the classification of grasslands of the world, but inevitably there is an element of arbitrariness about this (Coupland, 1979). The broadest division is between temper-ate and tropical grasslands and this review focuses on the first of these. Of the temperate grasslands of the world, some have grasslands as their natural vegetation and some are anthropo-genic in origin. In areas where 
grasslands are the natural climax vegetation (e.g. the steppes of central Asia and the prairies of North America), the rainfall is low enough to pre-vent the growth of forests

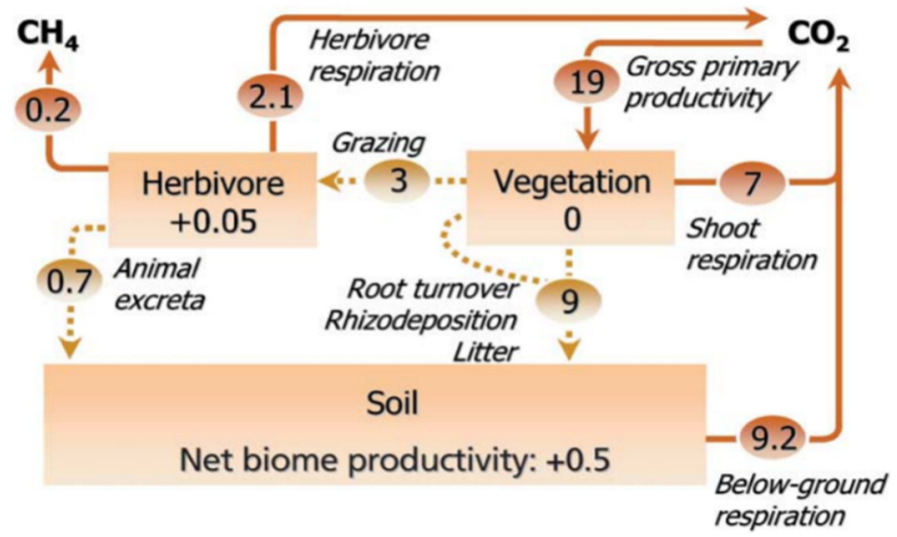

Figure 4: The carbon cycle in grazed grassland showing the annual net change $(\mathrm{Mg} \mathrm{C} \mathrm{ha-1} \mathrm{yr}-1)$ for herbivores, vegetation and soils, where net biome productivity is equivalent to $\mathrm{C}$ sequestration. The $\mathrm{C}$ fluxes are shown for intensively grazed grassland at an annual stocking density of 2 livestock units (LSU) ha-1. (Source: Soussana et al., 2004.)

Under existing management conditions, most temperate grasslands worldwide are considered to be $\mathrm{C}$ sinks. The higher rates in grasslands compared with arable systems is explained partly by greater supply of $\mathrm{C}$ to the soil under grassland ( Jackson et al., 1996) and partly by the increased residence time of $C$ resulting from the absence of disturbance by tilling. Additional reasons are: (i) a greater part of the input from root turnover and rhizode position is physically protected as POM; (ii) a large part of the POM is chemically stabilized (Gregorich et al., 2001); and (iii) aggre-gates tend to protect native organic matter from decomposition (Collins et al., 2000; Six et al .,2002).

Like carbon sequestration in forests or agricultural land, sequestration in grassland systems - primarily, but not entirely in the soils - is brought about by increasing carbon inputs. It is widely accepted that continuous excessive grazing is detrimental to plant communities (Milchunas and Lauenroth, 1993) and soil carbon stocks (Conant and Paustian, 2002a). When management practices that deplete soil carbon stocks are reversed, grassland ecosystem carbon stocks can be rebuilt, sequestering atmospheric CO2 (Follett, Kimble and Lal, 2001).

Using seeded grasses for cover cropping, catch crops and more complex crop rotations all increase carbon inputs to the soil by extending the time over which plants are fixing atmospheric $\mathrm{CO}_{2}$ in cropland systems. Rotations with grass, hay or pasture tend to have the largest impact on soil carbon stocks (West and Post, 2002). Adding manure to soil builds soil organic matter in grasslands (Conant, Paustian and Elliott, 2001).

According to IPCC (2007a), the technical potential for reduction of $\mathrm{CH}_{4}$ emissions from manure estimates to be $12.3 \mathrm{Tg} \mathrm{C}$ yr-1 by $2030 ; \mathrm{N}_{2} \mathrm{O}$ emissions could also be reduced. Adding manure in one place to build soil carbon stocks is offset by removal or what would be carbon inputs in another place (by forage or feed harvest).

Globally, an estimated $0.2-0.8 \mathrm{Gt} 2 \mathrm{CO} 2 \mathrm{yr}-1$ could be sequestered in grassland soils by 2030 , given prices for $\mathrm{CO}_{2}$ of USD20-50/tonne (IPCC, 2007a).

Estimated rates of carbon sequestration per unit are lower than those for sequestration on agricultural land, but sequestration potential is comparable to that of croplands because grasslands cover such a large portion of the earth's surface million ha of grassland worldwide have been degraded to some degree by mismanagement (Bridges and Oldeman, 1999).

Grasslands contain a substantial amount of the world's soil organic carbon. Integrating data on grassland areas (FAOSTAT, 2009) and grassland soil carbon stocks (Sombroek, Nachtergaele and Hebel, 1993) results in a global estimate of about 343 billion tonnes of $\mathrm{C}$ - nearly 50 percent more than is stored in forests worldwide (FAO, 2007).

Just as in the case of forest biomass carbon stocks, grassland soil carbon stocks are susceptible to loss upon conversion to other land uses (Paustian, Collins and Paul, 1997) or following activities that lead to grassland degradation (e.g. overgrazing). Over the last decade, the grassland area has been diminishing while arable land area has been growing, suggesting continued conversion of grassland to croplands (FAOSTAT, 2009). When grasslands are converted to agricultural land, soil carbon stocks tend to decline by an average of about 60 percent (Guo and Gifford, 2002).

Grassland management practices that sequester carbon tend to make systems more resilient to climate variation and climate change: increased soil organic matter (and carbon stocks) increases yields (Pan et al., 2006); soil organic matter also enhances soil fertility; reducing reliance on external $\mathrm{N}$ inputs (Lal, 2009b). 


\subsection{Terrestrial Carbon stocks in Ethiopia}

Ethiopia is located at $2^{\circ} 54^{\prime} \mathrm{N}-15^{\circ} 18^{\prime} \mathrm{N}$ latitude and $32^{\circ} 42^{\prime} \mathrm{E}-48^{\circ} 18^{\prime} \mathrm{E}$ longitude. It is a land-locked country with a land area of 1.12 million $\mathrm{km} 2$ occupying a significant portion of the Horn of Africa. The country has diverse climate, geology and topography resulting in heterogeneity of soil types (Hurni et al., 2007; Mesfin, 1998). The forest resources of Ethiopia store 2.76 billion tons of carbon (about 10 billion tons of $\mathrm{CO} 2$ equivalents) in the Above Ground Biomass (AGB) (Moges et al., 2010). However, the forest resources in Ethiopia have experienced so much pressure due to the increasing need for wood products and conversion to agriculture. Indigenous conservation practices of forest resources in Southern Ethiopia are traditionally well developed. The south-western part of Ethiopia accounts for 18\% of the country's forest cover (Menker and Rashid, 2012). Ethiopia does not have carbon accumulation records databank to monitor and enhance carbon sequestration potential of different forests. According to Moges et al., (2010) report, Ethiopia woodlands are covering large areas and their carbon stock is much higher than high forests which are 1,263.13 million tons of carbon per 29.55 million hectare in woodland and 434.19 million tons of carbon per 4.07 million hectare in the high forest.

National soil database carbon pools estimate, which currently does not exist in Ethiopia (Okolo et al., 2019). According to Adugna et al. (2013), information on carbon stocks of forest is limited in Ethiopia. Based on major landforms and altitudinal variations, the soils of Ethiopia can be grouped as highland and lowlands soils. The highlands of Ethiopia constitute more than $44 \%$ of the total area of the country (FAO, 1984) Vegetation and soil degradation are serious problems in both the highlands and lowlands of Ethiopia (EFAP, 1994)

Although there are case studies on soil carbon pools for selected parts of Ethiopia (Girmay et al., 2008) estimate on national soil carbon pools is missing. In spite of the limited knowledge of soils, data, variability and various forms of soil carbon and factor influencing the pools, attempt was done to estimate soil carbon pool in Ethiopia. (Table 1). The estimate was based on bulk density figures from African Highland Initiative (AHI 1997) and Mesfin (1998). Soil profile data were used from UNDP/FAO (1984) and estimates from Batjes (1996). Soil carbon stocks (tonnes $\mathrm{C} / \mathrm{ha}$ ) was calculated based on carbon concentration (\%) and bulk density (BD) for each mean depth in the soil unit as described in Jones (2007).

Table 6: Preliminary Estimate of Soil Organic Carbon pool in Ethiopia

\begin{tabular}{|c|c|c|c|c|c|}
\hline \multirow{2}{*}{$\begin{array}{l}\text { Soil } \\
\text { Units** }\end{array}$} & \multirow{2}{*}{$\begin{array}{l}112 \text { mill ha* } \\
\text { land } \\
\text { area } \\
\text { cover**) }\end{array}$} & \multicolumn{2}{|c|}{ Soil Organic Carbon (SOC) } & \multirow{2}{*}{$\begin{array}{l}\text { +Density } \\
\left(\mathrm{Mg} / \mathrm{m}^{3}\right)\end{array}$} & \multirow{2}{*}{$\begin{array}{l}\text { SOC distribution for depth }(0- \\
100 \mathrm{~cm})++\left(\mathrm{kg} / \mathrm{m}^{2}\right)\end{array}$} \\
\hline & & $\begin{array}{l}\text { Density } \\
\text { (tons/ha) }+++\end{array}$ & $\begin{array}{l}\text { Pool } \\
\text { (Billion } \\
\text { tons) }\end{array}$ & & \\
\hline Nitosols & 14.40 & 143 & 2.05 & 1.43 & 8.4 \\
\hline Cambisols & 12.00 & 136 & 1.63 & 1.36 & 9.6 \\
\hline Vertisols & 11.90 & 150 & 1.78 & 1.50 & 11.1 \\
\hline Luvisols & 6.00 & 154 & 0.92 & 1.54 & 6.5 \\
\hline Fluvisols & 6.20 & 140 & 0.86 & 1.40 & 9.3 \\
\hline Xerosols & 5.40 & 149 & 0.80 & 1.49 & 4.8 \\
\hline Solonchaks & 0.22 & 148 & 0.03 & 1.48 & 4.2 \\
\hline Acrisols & 1.80 & 141 & 0.25 & 1.41 & 9.4 \\
\hline Others & 42.08 & 140 & 5.89 & 1.40 & 13.1 \\
\hline
\end{tabular}

**Hurni et al (2007) * Source CSA (2010) + (See also +++) +mean bulk density for profile AHI (1997) \& Mesfin $(1998)++$ mean distribution along profile $(0-100 \mathrm{~cm})$ is $50 \mathrm{~cm}$ for shallow soils (supplementary fact) + mean profile depth, organic carbon was based on AHI (1997), data from UNDP/FAO (1984) and Batjes (1996). 
Table 7: Carbon stock potential of different forest ecosystems of Ethiopia.

\begin{tabular}{|l|l|l|l|l|l|}
\hline \multirow{2}{*}{ Name } & T ha-1 & \multicolumn{5}{l|}{ TCS } \\
\cline { 2 - 6 } & AGBC & BGBC & LHGsBC & SOC & T \\
\hline Adaba-Dodola CF Bazezew et al.,2014) & 278.03 & 41.76 & 1.06 & 186.4 & 507.29 \\
\hline Danaba CF (Bazezew et al., 2015) & 278.03 & 41.76 & 1.06 & 186.4 & 507.29 \\
\hline Egdu forest (Yohannes et al., 2015) & 278.08 & 55.62 & 3.47 & 277.6 & 614.72 \\
\hline Humbo forest (Chinasho et al., 2015) & 30.77 & 14.46 & 12.55 & 168.2 & 225.98 \\
\hline MauntZequalla forest (Girma et al., 2014) & 273.2 & 47.6 & 6.5 & 57.6 & 348.8 \\
\hline Tara Gedam forest (Gedefaw, 2015) & 306.66 & 61.52 & 0.9 & 274.3 & 643.11 \\
\hline Zequala Monastery forest(Girma et al., 2014) & 237.20 & 47.60 & 6.99 & 57.62 & 349.41 \\
\hline Meskel Gedam forest(Dagnachew Tefera, 2016) & 146.34 & 29.27 & 3.03 & 131.79 & 310.43 \\
\hline Anbessa forest(Yilma et al., 2010) & 169.02 & 34 & 1.15 & 149 & 353 \\
\hline Sekelemariyam State forest(Yitayal, 2016) & 119.88 & 24.34 & 101.56 & 3.69 & 249.48 \\
\hline Gera forest(Hassen, 2015) & 217.27 & 43.54 & 5.08 & 172.62 & 440.71 \\
\hline Simien Mountain NP (Assaye and Asrat, 2016) & 57.83 & 13.88 & 0.85 & 92.7 & 165.26 \\
\hline Selected church forest in Addis Ababa(Tolla, 2011) & 122.85 & 25.97 & 4.95 & 135.94 & 289.6 \\
\hline Gesha-Sayilem forest(Admassu et al.,2019) & 164.5 & 32.9 & 1.27 & 137.67 & 362.4 \\
\hline
\end{tabular}

AGBC and BGBC- above ground and below ground biomass carbon stock; TCS-total carbon stock; LHDsBClitter, herbs and grasses biomass carbon; $\mathrm{CF}$ - community forest

\section{CONCLUSION AND RECOMMENDATIONS}

Global warming is among the greatest terrible horrors of the modern times. It is believed that carbon is among the most significant casual factors which cause global warming. In terrestrial system, in which carbon is retained in live biomass, decomposing organic matter and soil play an important role in the global carbon cycle. Carbon is exchanged between these systems and the atmosphere through photosynthesis, respiration, decomposition and combustion. Human activities are responsible for making changes in carbon stocks in these pools by changing the land use pattern of any area.

Forests sequester and store more carbon than any other terrestrial ecosystem and are an important natural 'brake' on climate change. When forests are cleared or degraded, their stored carbon is released into the atmosphere as carbon dioxide (CO2). Roots are an essential yet poorly understood component of terrestrial ecosystems. They play an important role in the carbon (C) cycle by contributing a significant fraction of ecosystem net primary production. Soil organic matter is a chief contributor to the carbon stocks of forests after AGB and soils, which are the major sources of carbon emissions following the deforestation.

The implementation of improved land management practices to build up carbon stocks in terrestrial ecosystems is a proven technology for reducing the concentration of carbon dioxide (CO2) in the atmosphere offsetting emissions from other sources and drawing down atmospheric $\mathrm{CO} 2$.

The large populations of people who depend directly on grasslands tend to be poor and vulnerable to climate variability and climate change. Implementing practices to build - or rebuild - soil carbon stocks in grasslands could lead to considerable mitigation, adaptation and development benefits.

\section{RECOMMENDATIONS}

Afforestation is highly recommended as an effective measure to prevent the global warming by sequestrating $\mathrm{C}$ both in biomass and in soil.

Implementing strategies available for lowering $\mathrm{CO}_{2}$ emissions to mitigate climate change, such as (i) Reducing global energy use; (ii) developing low or no-C fuel; and (iii) sequestering $\mathrm{CO} 2$ from point sources or atmosphere using natural and engineering techniques.

Concerted effort should be made by different stakeholder in supporting agroforestry.

The idea of Reducing Emissions from Deforestation and forest Degradation (REDD) which was conceived by (UNFCCC) should be effectively implemented as the main carbon emission reduction mechanism by developing countries like Ethiopia.

Forest management should be enhanced and proposed as a way to mitigate the impacts of climate change and sustain the supply of ecosystem goods and services.

Developing effective policies capable of growing terrestrial carbon sinks is a primal strategy for effective achievement in reducing the effect of global warming.

\section{REFERENCE}

Admassu A., S. Demissew., T. Soromessa. and Z. Asfaw. (2019). Carbon Stock of the Moist Afromontane Forest in Gesha and Sayilem Districts in Kaffa Zone: An Implication for Climate Change Mitigation. Journal of 
Ecosystem \& Ecography. DOI: 10.4172/2157-7625.1000259.

Adugna F, T.Soromessa, Mekuria A. (2013). Forest carbon stocks and variations along altitudinal gradients in Egdu forest: implications of managing forests for climate change mitigation. Sc Technol Art Res J. 2013;2(4):40-6.

Ajayi OC, Akinni fesi FK, Sileshi G, Chakeredza S. (2007). Adoption of renewable soil fertility replenishmenttechnologies in the southern African region: lessons learnt and the way forward. Nat Resour Forum 31:306-317.

Albrecht A, Kandji ST. (2003). Carbon sequestration in tropical agroforestry systems. Agric Ecosyst Environ 99:15-27

Andrasko, K. (1990). Global warming and forests: an overview of current knowledge. Unasylva4l: 3-11.

Asner GP, Elmore AJ, Olander LP, Martin RE, Harris AT. (2004). Grazing systems, ecosystem responses, and global change. Annual Review of Environment and Resources 29: 261-299.

Assaye H, Z. Asrat. (2016). Carbon storage and climate change mitigation potential of the forests of the simien mountains national park, Ethiopia. Agriculture, Forestry and Fisheries 5: 8-17.

Bader N, Cheng W. (2007). Rhizosphere priming effect of Populus fremontii obscures the temperature sensitivity of soil organic carbon respiration. Soil Biol Biochem 39:600-606

Baes CF Jr, Goeller HE, Olson JS, Rotty RM. (1970). Carbon dioxide and climate: the uncontrolled experiment. Am Sci 1977, 65:310-320. 20. Bolin B: The carbon cycle. Sci Am 1970, 233:124-132.

Batjes NH. (1996). Total C and N in soils of the world. Eur J Soil Sci 1996, 47:151-163.

Bazezew, M.N. (2014). Carbon Stock in Adaba-Dodola Community Forest of Danaba District, West-Arsi Zone of Oromia Region, Ethiopia: An Implication for Climate Change Mitigation. MSc thesis, Addis Ababa University, Ethiopia.

Bazezew, M.N., Soromessa, T. and Bayable, E. (2015). Above- and Below-Ground Reserved Carbon in Danaba Community Forest of Oromia Region, Ethiopia: Implications for CO2 Emission Balance. American Journal of Environmental Protection, 4(2): 75-82. doi: 10.11648/j.ajep.20150402.11.

Bhardwaj SD, Panwar P. (2003). Global warming and climate change-effect and strategies for its mitigation. Indian Forester 129: 741-748.

Bonan GB. (2014). Connecting mathematical ecosystems, real-world ecosystems, and climate science. New Phytol 202:731-733

Bridges, E.M. \& Oldeman, L.R. (1999). Global assessment of human-induced soil degradation. Arid Soil Res. Rehabil., 13: 319-325.

Brown S. (1995). Management of forests for mitigation of greenhouse gas emissions, in Climatic Change, Impacts, Adaptations and Mitigation of Climate Change: Scientific-Technical Analyses (Eds. Houghton JT, Jenkins GJ, and Ephraums JJ Cambridge: Cambridge University Press 773-797.

Brown S. (2002). Measuring carbon in forests: current status and future challenges. Environ Pollut 116:363-372

Brown, A. G., Nambiar, E. K. S. \& Cossalter, C. (1997). Plantations for the tropics-their role, extent and nature. Pp. 1-24 in Nambiar, E. K. S. \& Brown, A. (Eds.) Management of Soil, Nutrients and Water in Tropical Plantation Forests. ACIAR Monograph No. 43. Australian Centre for International Agricultural Research, Canberra.

Brown, S. and P. Leonard. (2004). Biosolids and Global Warming: Evaluating the Management Impacts," Biocycle, August.

CAIRNS, M. A. \& MEGANCK, R. A. (1994). Carbon sequestration, biological diversity, and sustainable development: integrated forest management. Environmental Management 18(1): 13-22.

Chakravarty S, Ghosh S, Suresh C, Dey A and Shukla G. (2011). Deforestation: Causes, Effects and Control Strategies. Global Perspectives on Sustainable Forest Management 3-21.

Chinasho, A., Soromessa, T. and Bayable. E. (2015). Carbon stock in woody plants of Himbo forest and its variation along altitudinal gradients: The case of Humbo district, Wolaita Zone, Southern Ethiopia. International journal of environmental protection and policy, 3(4): 97-103. doi: 10.11648/j.ijepp.20150304.13.

Chukwuebuka C. Okolo, Girmay Gebresamuel, Abeba N. Retta, Amanuel Zenebe and Mitiku Haile1. (2019). Advances in quantifying soil organic carbon under different land uses in Ethiopia: a review and synthesis.

Collins HP, Elliott ET, Paustian K, Bundy LC, Dick WA, Huggins DR, Smucker AJM, Paul EA. (2000). Soil carbon pools and fluxes in long-term Corn Belt agroecosystems. Soil Biology and Biochemistry 32: 157-168.

Conant, R.T. \& Paustian, K. (2002a). Potential soil carbon sequestration in overgrazed grassland ecosystems. Global Biogeochem. Cycles, 16: 1143

Coupland RT. (1979). The nature of grassland. In: Coupland RT, ed. Grassland ecosystems of the world. Cambridge, UK: Cambridge University Press, 23-31.

Craswell, E. T. and Lefroy, R. D. B. (2001). The role and function of organic matter in tropical soils, Nutr. Cycl. Agroecosys., 61, 7-18,.

CRS Report RL31432, (2007). Carbon Sequestration in Forests, by Ross W. Gorte 
Dixon RK. (1995). Agroforestry systems: sources and sinks of greenhouse gases? Agrofor. Syst. 31: 99-116.

Drake JE, Gallet-Budynek A, Hofmockel KS et al. (2011). Increases in the flux of carbon belowground stimulate nitrogen uptake and sustain the longterm enhancement of forest productivity under elevated CO2. Ecol Lett 14:349-357

EFAP. Ethiopian Forestry Action Plann. (1994). Ministry of National Resources Development and Environmental Protection: Addis Ababa, 1994. Vol. 1 and 2;

Eswaran H, Vandenberg E, Reich P. (1993). Organic carbon in soils of the world. Soil Science Society of America Journal 57: 192-194.

Fang JY, Guo ZD, Piao SL et al. (2007). Terrestrial vegetation carbon sinks in China, 1981-2000. Sci China Ser D Earth Sci 50(9):1341-1350

FAO. (2005). FAO Statistical database 2005 available at http://faostat.fao.org/ (accessed 2005-09-06)

FAO. (2008). Expert meeting on climate change adaptation and mitigation, 5-7 March 2008 for the High-Level Conference on World Food Security: the Challenges of Climate Change and Bioenergy, Rome.

FAO. Ethiopian Highlands Reclamation Study (EHRS). (1984). Final report. Food and Agriculture Organization of the United States (FAO): Rome, 1984; Vol. 1-2.

FAOSTAT. (2009). Statistical Database 2007. Rome.

Field C, Behrenfeld M, and Randerson J, Falkowski P. (1998). Primary production of the biosphere: integrating terrestrial and oceanic components. Science 281: 237-240.

Finzi AC, Van Breemen N, Canham CD. (1998). Canopy tree soil interactions within temperate forests: Species effects on soil carbon and nitrogen. Ecol Appl 8:440-446

Follett, R.F., Kimble, J.M. \& Lal, R., eds. (2001). The potential of US grazing lands to sequester carbon and mitigate the greenhouse effect. Boca Raton, USA, CRC Press LLC.

Fontaine, S., Barot, S., Barre, P., Bdioui, N., Mary, B., and Rumpel, C. 2007. Stability of organic carbon in deep soil layers controlled by fresh carbon supply, Nature, 450, 277-281,

Franzluebbers, A.J., Chappell, J.C., Shi, W., Cubbage, F.W. (2017). Greenhouse gas emissions in an agroforestry system of the southeastern USA. - Nutrient Cycling in Agroecosystems 108: 85-100.

Gahagan A, Giardina CP, King JS, Binkley D, Pregitzer KS, Burton AJ. (2015). Carbon fluxes, storage and harvest removals through 60years of stand development in red pine plantations and mixed hardwood stands in Northern Michigan, USA. Forest Ecology and Management 337: 88ะ97.

Gaudinski JB, Trumbore SE, Davidson EA et al. (2001). The age of fine-root carbon in three forests of the eastern United States measured by radiocarbon. Oecologia, 129, 420-429.

Girma, A., T. Soromessa, and T. Bekele. (2014). Forest carbon stocks in woody plants of mount Zequalla Monastery and its variation along altitudinal gradient: implication of managing forests for climate change mitigation. Star journal, 3(2):132-140.doi: 10.4314/star.v3i2.17.

Gower ST, Kucharik CJ, Norman JM. (1999). Direct and Indirect Estimation of Leaf Area Index, fAPAR, and Net Primary Production of Terrestrial Ecosystems. Remote Sensing of Environment 70: $29 \pm 51$.

Gregorich EG, Drury CF, Baldock JA. (2001). Changes in soil carbon under long-term maize in monoculture and legume-based rotation. Canadian Journal of Soil Science 81: 21-31.

Gregory, A., Dungait, J., Watts, C., Bol, R., Dixon, E., White, R., and Whitmore, A. (2016). Long-term management changes topsoil and subsoil organic carbon and nitrogen dynamics in a temperate agricultural system, Eur. J. Soil Sci., 67, 421-430,

Griscom, B. W., Adams, J., Ellis, P. W., Houghton, R. A., Lomax, G., Miteva, D. A., Schlesinger, W. H., Shoch, D., Siikamäki, J. V., Smith, P., Woodbury, P., Zganjar, C., Blackman, A., Campari, J., Conant, R. T., Delgado, C., Elias, P., Gopalakrishna, T., Hamsik, M. R., Herrero, M., Kiesecker, J., Landis, E., Laestadius, L., Leavitt, S. M., Minnemeyer, S., Polasky, S., Potapov, P., Putz, F. E., Sanderman, J., Silvius, M., Wollenberg, E., ... Fargione, J. (2017). Natural climate solutions. Proceedings of the National Academy of Sciences of the United States of America, 114(44), 11645-11650.

Guo, L.B. \& Gifford, R.M. (2002). Soil carbon stocks and land use change: a meta-analysis. Glob. Change Biol., 8: $345-360$

Haile, S. G., Nair, P. K. R., Nair, V. D. (2008). Carbon storage of different soil-size fractions in Florida silvopastoral systems.J. Environ. Qual. 37, 1789-1797.

Harris, N. L.et al. (2012). Baseline map of carbon emissions from deforestation in tropical regions. Science 336, $1573-1576$.

Hassen N. (2015). Carbon stock estimation along an altitudinal gradient in Gera moist ever green afromontane forest, Southwest Ethiopia. M.Sc. Thesis, Addis Ababa University.

Hurni H, Amare Bantider, Herweg K, Portner, B and H. Veit. (2007). Landscape Transformation and Sustainable Development in Ethiopia. Background Information for a study tour through Ethiopia, September 4-20, 2006, CDE (Center for Development and Environment) University of Bern, Bern, 321pp

Hurni, H. (1988). Degradation and conservation of the resources in the Ethiopian highlands. Mt. Res. Dev. 1988, 


\section{$8,123-130$.}

IPCC. (1996). Climate change 1995, Impacts, adaptation and mitigation of climate change: Scientific, technical analysis, contribution of working group II to the 2 nd assessment reports of the IPCC. Intergovernmental Panel on Climate Change. Cambridge University Press, Cambridge UK.

IPCC. (2001). Climate change 2001: the scientific basis. Contribution of working group 1 to the third assessment report of the intergovernmental panel on climate change. Houghton JT, Ding Y, Griggs DJ, Noguer M, van der Linden PJ, Dai X, Maskell K, Johnson CA, eds. Cambridge, UK: Cambridge University Press.

IPCC. (2007). Climate change 2007: The physical science basis (Cambridge University Press, Cambridge, UK and New York, USA, 2007).

IPCC. (2007a). Climate Change 2007: Mitigation. Contribution of Working Group III to the Fourth Assessment Report of the Intergovernmental Panel on Climate Change. B. Metz, O.R. Davidson, P.R. Bosch, R. Dave \& L.A. Meyer, eds. Cambridge, UK, and New York, USA, Cambridge University Press.

IPCC. (2019). IPCC Special Report on Climate Change, Desertification, Land Degradation, Sustainable Land Management, Food Security, and Greenhouse gas fluxes in Terrestrial Ecosystems. Intergovernmental Panel on Climate Change.

Jackson RB, Canadell J, Ehleringer JR, Mooney HA, Sala OE, Schulze ED. (1996). A global analysis of root distributions for terrestrial biomes. Oecologia 108: 389-411.

Jipp PH, Nepstad DC, Cassel DK et al. (1998). Deep soil moisture storage and transpiration in forests and pastures of seasonally dry Amazônia. Climatic Change, 39, 395-412.

Jose S. (2009) Agroforestry for ecosystem services and environmental benefits: an overview. Agrofor Syst 76:110

Karjalainen T, Pussinen A, Liski J et al. (2003). Scenario analysis of the impacts of forest management and climate change on the European forest sector carbon budget. For Policy Econ 5:141-155

Kaur B, Gupta SR, Singh G. (2002). Carbon storage and nitrogen cycling in silvopastoral systems on a sodic soil in north-western India. Agroforestry Systems 54: 21-29.

Keenan T.F. and Williams C.A. (2018). The Terrestrial Carbon Sink. Annual Review and Environmental Resource. 43:219-43. Earth Sciences Division, Lawrence Berkeley National Laboratory, Berkeley, California 94720, USA.

Kirby, K. R., Potvin, C. (2007). Variation in carbon storage amongtree species: Implications for the management of a small-scalecarbon sink project. For. Ecol. Manage. 246, 208-221.

Kong, A. Y. and Six, J. (2010). Tracing root vs. residue carbon into soils from conventional and alternative cropping systems, Soil Sci. Soc. Am. J., 74, 1201-1210.

Lal, R. (2004). Soil Carbon Sequestration impacts on global climate change and food security. Science 304:16231627.

Lal, R. (2009b). Soils and food sufficiency: a review. Agronomy for Sustainable Development, 29: $113-133$.

Lefèvre, C., Rekik, F., Alcantara, V., \& Wiese, L. (2017). Soil organic carbon: the hidden potential. Food and Agriculture Organization of the United Nations (FAO).

Lefèvre, C., Rekik, F., Alcantara, V., \& Wiese, L. (2017). Soil organic carbon: the hidden potential. Food and Agriculture Organization of the United Nations (FAO).

Lieth H. (1975). Modeling the primary productivity of the world. In: Lieth H, Whittaker RH (Eds.) Primary Productivity of the Biosphere. Springer-Verlag, New York. 237-263.

Luedeling E, Sileshi G, Beedy T, Dietz J. (2011). Carbon sequestration potential of agroforestry systems in Africa. In: Kumar BM, Nair PKR (eds) Carbon sequestration potential of agroforestry systems: opportunities and challenges. Springer Science+Business Media B.V., Dordrecht, pp. 61-83

Mahecha, M. D. et al. (2010). Global convergence in the temperature sensitivity of respiration at ecosystem level. Science 329, 838-840

Malhi Y and Grace J. (2000). Tropical forests and atmospheric carbon dioxide Trends Ecol. Evolut. $15332-7$

Menker, H. and M.H. Rashid. (2012). Drivers of land-use change in the Southern Nations, Nationalities and People's Region of Ethiopia. African Journal of Agriculture and Resource Economics, 9(2): 148-164.

Mesfin, A. (1988). The Nature and Management of Ethiopian Soils, Alemaya University of Agriculture (AUA), Ethiopia. $272 \mathrm{pp}$

Milchunas, D.G. \& Lauenroth, W.K. (1993). Quantitative effects of grazing on vegetation and soils over a global range of environments. Ecol. Monogr., 63: 327-366.

Moges, Y., Z. Eshetu, and S. Nune. (2010). Ethiopian Forest Resources: Current Status and Future Management Options in View of Access to Carbon Finances. Literature Review for Ethiopian Climate Research and Networking and the United Nations Development Program. Addis Ababa, Ethiopia.

Montagnini, F. \& Porras, C. (1998). Evaluating the role of plantations as carbon sinks: an example of an integrating approach from the humid tropics. Environmental Management 22:459-470.

Morgan JA, Follett RF, Allen LH, Del Grosso S, Derner JD, Dijkstra F, Franzluebbers A, Fry R, Paustian K and 
Schoeneberger MM. (2010). Carbon sequestration in agricultural lands of the United States. Journal of Soil and Water Conservation 65(1): 6A-13A. DOI: 10.2489/jswc.65.1.6A

Moulton, R.J., Richards, K.R. (1990). Costs of Sequestering Carbon through Tree Planting and Forest Management in the United States. USDA Forest Service, General Technical Report WO-58, Washington, DC.

Nabuurs GJ, Hengeveld GM, Werf DC et al. (2010). European forest carbon balance assessed with inventory based methods - an introduction to a special section. For Ecol Manag 260:239-240

Nair PKR, Nair VD, Kumar BM, Haile SG. (2009b). Soil carbon sequestration in tropical agroforestry systems: a feasibility appraisal. Environ Sci Pol 12:1099-1111

Nair PKR. (1998). Directions in tropical agroforestry research: Past, present, and future. Agro. For. Syst. 38: 223245.

Nair PKR. (2007). Agroforestry for sustainability of lower-input land-use systems. J Crop Improv 19:25-47

Nair, P.K.R., Kumar, B.M. \& Nair, V.D. (2009). Agroforestry as a strategy for carbon sequestration. Journal of Plant Nutrition and Soil (Science-Zeitschrift für Pflanzenernahrung und Bodenkunde). 172: 10-23.

Negi JDS, Chauhan PS. (2002). Greenhouse gases mitigation potential by Sal forest in Doon Valley. Indian Forester 128: 771-778.

Nepstad DC, Decarvalho CR, Davidson EA et al. (1994). The role of deep roots in the hydrological and carbon cycle of Amazonian forests and pastures. Nature, 372, 666-669.

Neufeldt, H., Jahn, M., Campbell, B.M., Beddington, J.R., DeClerck, F., De Pinto, A., Gulledge, J., Hellin, J., Herrero, M., Jarvis, A. (2013). Beyond climate-smart agriculture: toward safe operating spaces for global food systems. Agriculture \& Food Security, 2, 12,

Noble I, Bolin B, Ravindranath N, Verardo D and Dokken D. (2000). Land use, land use change, and forestry: Cambridge University Press.

Nosberger J, Blum H, Fuhrer J. (2000). Crop ecosystem responses to climatic change: Productive grasslands. In: Hodges HF (Ed.), Climate Change and Global Crop Productivity, CAB International, Wallingford, UK. 271291.

Nowak, D.J. (1994). Atmospheric carbon dioxide reduction by Chicago's urban forest. In: McPherson, E.G., Nowak, D.J., Rowntree, R.A. (Eds.), Chicago's Urban Forest Ecosystem: Results of the Chicago Urban Forest Climate Project. USDA Forest Service General Technical Report NE-186, Radnor, PA, pp. 83-94.

Pan, Y., Birdsey, R.A., Hom, J., McCullough, K. \& Clark, K. (2006). Improved satellite estimates of net primary productivity from MODIS satellite data at regional and local scales. Ecol. Appl., 16: 125-132.

Paul KI, Polglase PJ, Nyakuengama JG, Khanna PK. (2002). Change in soil carbon following afforestation. For Ecol Manag 168:241-257

Post WM, Izaurralde RC, Mann LK, Bliss N. (2001). Monitoring and verifying changes of organic carbon in soil. Climate Change 2001, 51:73-99.

Prentice IC, Farquhar GD, Fasham MJR, Goulden ML, Heimann M, Jaramillo VJ, Kheshgi HS, Le Quéré C, Scholes RJ, Wallace DWR. (2001). The carbon cycle and atmospheric carbon dioxide. In: Houghton JT, Ding Y, Griggs DJ, Noguer M, van der Linden PJ, Dai X, Maskell K, Johnson CA, eds. Climate change 2001: the scientific basis. Contribution of working group 1 to the third assessment report of the intergovernmental panel on climate change. Cambridge, UK: Cambridge University Press, 183-239

Rao KPC, Verchot LV, Laarman J. (2007). Adaptation to Climate Change through Sustainable Management and Development of Agroforestry Systems. SAT eJournal 4: 1-30.

Reeder JD, Franks CD, Milchunas DG. (2001). Root biomass and microbial processes. In: Lal R (Ed.). The Potential of U.S. Grazing Lands to Sequester Carbon and Mitigate the Greenhouse Effect. CRC Press, Boca Raton, FL, USA. p. 139-166

Reid, R. Thornton, P.K., McCrabb, G.J., Kruska, R.L., Atieno, F. \& Jones P.G. (2004). Is it possible to mitigate greenhouse gas emissions in pastoral ecosystems of the tropics? Environment, Development and Sustainability, 6: 91-109.

Richard, L., Charles, Emmanuel, F., Nzunda \& Munishi, P.K.T. (2014). Agroforestry as a Resilient Strategy in Mitigating Climate Change in Mwanga District, Kilimanjaro, Tanzania.

Richards JF, Flint EP. (1993). Historic Land use and Carbon Estimates for South and South East Asia: 1880-1980. ORNL/CDIAC-61, NDP-46, Oak Ridge National Laboratory, Oak Ridge, Tennessee 404.

Roose, E. and Bathes, B. (2001). Organic matter management for soil conservation and productivity restoration in Africa: a contribution from Francophone research, Nutr. Cycl. Agroecosystem. 61, 159-170,

Samuel T. and A. Hailemicael. (2019). Carbon Sequestration Potential of Traditionally Managed Forest: Contributions to Climate Change Mitigation, Ethiopia. Australian Journal of Basic and Applied Sciences. DOI: 10.22587/ajbas.2019.13.2.1

Schlesinger W.H. \& Bernhardt E. (2013). Biogeochemistry: An analysis of global change. Durham: NC, Elsevier. Schoeneberger MM. (2009). Agroforestry: working trees for sequestering carbon on agricultural lands. Agroforestry Systems 75(1): 27-37. DOI: 10.1007/s10457-008-9123-8 
Schrag, D.P. (2007). Preparing to capture carbon. Science 315:812-813.

Schroeder P. (1993). Agroforestry systems: integrated land use to store and conserve carbon. Climate Research 3(1): 53-60. DOI: $10.3354 / \mathrm{cr} 003053$

Schroth, G., D’Angelo, S. A., Teixeira, W. G., Haag, D., Lieberei, R. (2002). Conversion of secondary forest into agroforestry and monoculture plantations in Amazonia: consequences for biomass, litter and soil carbon stocks after 7 years. For. Ecol. Manage. 163,131-150.

Six J, Conant RT, Paul EA, Paustian K. (2002). Stabilization mechanisms of soil organic matter: implications for C-saturation of soils. Plant and Soil 241: 155-176.

Smaling, E. and Dixon, J. (2006). Adding a soil fertility dimension to the global farming systems approach, with cases from Africa, Agr. Ecosyst. Environ., 116, 15-26,

Smith J. (2008). Greenhouse gas mitigation in agriculture. Philos Trans R Soc B-Biol Sci 363:789-813

Solomon, S. and Srinivasan, J. (1996). Radiative forcing of climate change. In, Climate Change 1995. Cambridge University Press. pp. 108-118.

Soussana JF, Loiseau P, Vuichard N, Ceschia E, Balesdent J, Chevallier T, Arrouays D. (2004). Carbon cycling and sequestration opportunities in temperate grasslands. Soil Use and Management 20: 219-230.

Spittlehouse, D.L. (2005). Integrating climate change adaptation into forest management. For. Chron. 81, 691695. Doi: $10.5558 / \mathrm{tfc} 81691-5$

Telles EDC, Camargo PB, Martinelli LA et al. (2003). Influence of soil texture on carbon dynamics and storage potential in tropical forest soils of Amazonia - art. no. 1040. Global Biogeochemical Cycles, 17, 1040.

Tian HQ, Chen G, Zhang C et al. (2012). Century-scale response of ecosystem carbon storage and flux to multifactorial global change in the Southern United States. Ecosystems 15:674-694

Tolla T. (2011). Estimation of carbon stock in church forests: Implications for managing Church forest for carbon emission reduction. Unpublished MSc thesis, Addis Ababa University, Ethiopia.

Vagen, T. G., Lal, R., and Singh, B. R. (2005). Soil carbon sequestration in sub-Saharan Africa: a review, Land Degrad. Dev., 16, 53-71,

Vanderhaegen, K., Verbist, B., Hundera, K., Muys, B. (2015). REALU vs. REDD+: Carbon and biodiversity in the Afromontane landscapes of SW Ethiopia. For. Ecol. Manage. 343, $22-33$. doi:10.1016/j.foreco.2015.01.016

Vogt KA, Vogt DJ, Palmiotto PA et al. (1996). Review of root dynamics in forest ecosystems grouped by climate, climatic forest type and species. Plant and Soil, 187, 159-219.

Wang SQ, Zhou CH, Luo CW. (1999). Studying carbon storage spatial distribution of terrestrial natural vegetation in China. Prog. Geogr. 18: 238-244.

West, T.O. \& Post, W.M. (2002). Soil organic carbon sequestration rates by tillage and crop rotation: a global data analysis. Soil Sci. Soc. Am. J., 66: 1930-1946.

WMO. (2010). Greenhouse Gas Bulletin: The state of the greenhouse gases in the atmosphere until December.

Yitayal Tebeje. (2016). Carbon Stock Estimation of Forests for Climate Change Mitigation. LAP LAMPRT Academic Publishing, Deutschland/Germany. Available at: www.morebooks.de

Yohannes, H., T. Soromessa, M. Argaw, 2015. Carbon Stock Analysis Along Altitudinal Gradient in Gedo Forest: Implications for Forest Management and Climate Change Mitigation. American Journal of Environmental Protection, 4(5): 237-244. doi: 10.11648/j.ajep.2015 0405.14.

Yu D, Wang X, Yin Yet al. (2014). Estimates of forest biomass carbon storage in Liaoning province of northeast China: a review and assessment. PLoS ONE 9(2):e89572. doi: 10.1371/journal. pone.0089572

Yurova, A. Y., Volodin, E. M., AaGREN, G. I., Chertov, O. G., \& Komarov, A. S. (2010). Effects of variations in simulated changes in soil carbon contents and dynamics on future climate projections. Global change biology, 16(2), 823-835. 